\title{
To log or not to log: local perceptions of timber management and its implications for well-being within a sustainable-use protected area
}

\author{
$\underline{\text { Natalie A. Cooper }}^{1}$ and $\underline{\text { Karen A. Kainer }}^{1,2}$
}

\begin{abstract}
Our research explores local perspectives of a recent and controversial shift in conservation and development strategies in the Brazilian Amazon whereby legal timber commercialization is being pioneered in select extractive reserves, which are a type of comanaged sustainable-use protected area. To understand how this initiative might affect well-being, we documented perceptions of reserve residents about a legal logging project and factors that influenced their decision to participate or not participate. Semistructured interviews $(N=64)$ were conducted with both male and female heads of household from June to August 2014. We tested the effect of household-level livelihood assets associated with material and relational well-being on project participation. Participating households were significantly less economically well-off and were more educated than nonparticipating households. Individual perceptions indicated that project supporters were motivated by income, whereas nonsupporters most frequently criticized the low price of timber. Both groups expressed concern about the potential environmental impacts of logging. By gender, supportive men were more motivated by financial aspects, whereas supportive women pointed to improved physical assets. Men opposed to the logging project highlighted governance issues, whereas nonsupportive women tended to express environmental concerns. Our study corroborates previously documented interests (and needs) of residents to develop alternative income-generating livelihood opportunities. Further, most interviewed residents expressed support for a more locally customized logging project, indicating that a lack of resident inclusion in project development generated much of the project controversy. Our study highlights both economic development and comanagement governance challenges of sustainable-use protected areas and how project interventions relate to well-being of forest residents.
\end{abstract}

Key Words: Brazilian Amazon; comanagement; extractive reserves; livelihoods; timber; well-being

\section{INTRODUCTION}

The number of protected areas worldwide doubled between the late 1990s and the late 2010s (Jenkins and Joppa 2009), with most of these new units integrating traditional peoples as conservation partners (Eringhaus 2005). Evidence suggests that, compared to strict protected areas, forest cover in the tropics is better maintained by such local communities (Ascher 1995, PorterBolland et al. 2012). Furthermore, forest systems in which local people participate in forest governance, especially rulemaking, can generate more sustainable conservation and livelihood outcomes for three key reasons: local participation incorporates local ecological knowledge into forest management, legitimizes rules, and strengthens accountability among resource users (Ostrom 1990, Gibson et al. 2000, McKean 2000, Hayes 2006, Persha et al. 2011). Brazil has far outpaced other countries in protected area expansion (Jenkins and Joppa 2009), creating numerous classifications of federal-, state-, and municipal-level sustainable-use conservation units. Across the Brazilian Amazon, these units collectively function to curb deforestation, to safeguard land rights of traditional populations, and to conserve biodiversity, natural resources, and environmental services (Imazon protected areas: http://imazon.org.br/slide/protectedareas-2/?lang=en).

The formal recognition of sustainable-use protected areas has often been accompanied by the establishment of comanagement arrangements to govern these systems. Comanagement describes a situation in which multiple actors negotiate, define, and share key management functions, entitlements, and responsibilities over an area or set of natural resources (Borrini-Feyerabend et al. 2000). Thus, this process decentralizes some amount of decisionmaking power and management responsibilities that were once concentrated in central governments to local populations (Ribot
2002). Often, communities are granted protection of their rights to exploit forest resources while the state maintains its supervisorial role to monitor and evaluate how residents use these resources (Cronkleton et al. 2012). The combinations of rights granted to local actors vary widely across systems, for example, by specific resource (i.e., rights to subterranean resources belong to the government while those aboveground belong to local residents) or how the resource is exploited (i.e., rights to harvest timber may differ from those to harvest fruits from the same forest).

In theory, comanagement should represent an ongoing, adaptive process of negotiation and problem solving. However, in practice, comanaged sustainable-use protected areas face onerous restrictions on resource use, power imbalances, and high transaction costs that can stifle local-level participation, benefit some individuals and communities more than others, and restrict the ability to adapt to changing conditions (Cronkleton et al. 2012). These systems are further tested by the complex and dynamic realities of social-ecological systems: variation in productivity of resource units, evolving governance systems, and the diversity of perceptions, interests, and relations among resource users and with external actors (Ostrom 2009). Sustainable use systems are relentlessly susceptible to pressure from road construction (Barber et al. 2014), deforestation, and illegal harvests (Imazon protected areas: http://imazon.org.br/ slide/protected-areas-2/?lang=en), especially when rules are poorly enforced (Keller et al. 2007, Agrawal et al. 2008). The conservation of these systems is inexorably challenged by the inability of under-resourced public institutions to handle the plethora of land-use change drivers (Lele et al. 2000, Boyd 2008) and the resulting disaffection among residents (Imazon protected areas: http://imazon.org.br/slide/protected-areas-2/?lang=en). 
Some comanaged sustainable-use forests have negotiated rights to extract timber as a means to balance dynamic development needs with established conservation goals, norms, or institutions, typically and specifically, to generate a fresh source of forestbased income while maintaining forest cover. Appropriately, maintaining contiguous forest cover is a fundamental metric for sustainable-use protected area performance and conservation generally, yet some degree of forest integrity is inevitably compromised by any amount of timber extraction. Low-intensity selective logging using reduced-impact logging practices presents a "middle way" between absolute forest conservation and deforestation (Putz et al. 2012:1). However, the extent to which forest communities benefit from timber management remains inconclusive (Pokorny and Pacheco 2014), and few communitybased logging initiatives have taken into account the varying local contexts and interests (Hajjar et al. 2013). Considering the many complexities inherent to comanagement of sustainable-use forests, local perceptions of how logging is approached and assessments of potential costs and benefits are critical to understanding trade-offs and synergies between conservation and well-being. Further, understanding the potential impacts of conservation-based interventions on local people's lives is fundamental to the success of such initiatives. Projects that embed local conceptions of well-being into their design can enhance conservation behavior and increase local engagement (Coulthard et al. 2011). The relevance of the local perspective is only heightened in the context of comanaged forests in which residents formally engage with system-wide resource management decisions.

Here, we explore the relationship between conservation and wellbeing in one type of comanaged sustainable-use protected area, the extractive reserve, in the state of Acre, Brazil. Specifically, we examine a logging project within the iconic Chico Mendes Extractive Reserve (CMER), one of the first of these reserves established and now among the first to experiment with legal logging to complement local livelihoods. We sought to contextualize and describe the logging project, to capture resident perceptions about this conservation-based initiative, and to understand the reasons motiving some residents to participate and others to decline. We addressed the following questions: (1) What factors influenced decisions to participate (or not) in logging? (2) How might the logging project affect various aspects of resident well-being?

Our concept of human well-being incorporates the idea that wellbeing embraces both the objective material and relational aspects of people's lives, as well as the subjective assessments reported by individuals about their own circumstances (Stiglitz et al. 2009, OECD 2011). Put simply, the multidimensional concept of wellbeing is a positive physical, social, and mental state (Summers et al. 2012). In the context of the extractive reserve, livelihoods are deeply and widely embedded in peoples' lives, and the logging project is expected to affect resident livelihoods. Livelihoods are the capabilities, assets (including both material and social resources), and activities that contribute to a means of living (Chambers and Conway 1991). Thus, we draw on the Sustainable Livelihoods Framework's five categories of assets that are used directly or indirectly to sustain livelihoods, i.e., physical, natural, financial, human, and social (Scoones 1998), to organize objective measures of well-being. Myriad and cross-cutting perceptions about the prospect of logging are expected to extend into the mental state of residents, and therefore, subjective well-being as it relates to the logging project may be evaluated by domain, including material well-being (i.e., secure and adequate livelihoods), social relations (i.e., good relations with family and community), security (i.e., confidence in the future, predictability and peace), and freedom of choice and action (i.e., sense of control and power; Woodhouse et al. 2015).

\section{Logging in extractive reserves?}

Extractive reserves are one type of sustainable use designated to $>11$ million ha across Brazil (SFB 2016). They can be considered a comanagement governance arrangement in which the government owns the land while traditional resident populations retain long-term usufruct rights via a renewable use concession (MMA 2006) to harvest and manage forest resources sustainably (Allegretti 1989). Although extractive reserves were designed specifically for sustainable extraction and conservation of renewable nontimber natural resources (e.g., tree exudates, fibers, fruits), timber is now being added to the menu of harvested resources in certain reserves (in addition to the Chico Mendes, three other federal extractive reserves have initiated logging projects: Ituxi in Amazonas, Verde Para Sempre in Pará, and Mapuá in Pará). Legal logging is fairly well established in several other categories of sustainable-use protected areas in Brazil (i.e., Humphries et al. 2015), but this is a new activity in extractive reserves.

In the Brazilian Amazon, community forest management and community-company partnerships are two broadly defined approaches to timber commercialization (Medina et al. 2009, Piketty et al. 2015). In the former model, communities are trained by external actors (e.g., nongovernmental organizations, government agencies) to implement management and harvest operations. This approach is heavily dependent on nongovernmental organizations and development agencies. In the latter model, community members sell their standing timber to external actors (often private logging companies), which can be beneficial for communities without proper organization, skills, equipment, and infrastructure to maximize sustainable timber yields. Such partnerships assist communities to overcome harvest costs and manage market risks by securing buyers, but these benefits potentially reduce economic returns and severely limit learning opportunities for communities (Medina et al. 2009, Piketty et al. 2015). Nevertheless, income generated may be substantial for participating rural households (Menton et al. 2009).

In addition to participation of internal vs. external actors, participation levels between men and women will likely influence logging outcomes. Forest conservation, to many women living in the Amazon region, is a means to familial health, cultural continuity, and a lifestyle that affords relative independence from oppression (Shanley et al. 2011). Also, an international study on the role of gender in natural resource management groups revealed that those groups with female participants, i.e., both mixed-gender and women's only groups, displayed increased collaboration, solidarity, and conflict resolution (Westermann et al. 2005). 


\section{Chico Mendes Extractive Reserve}

The extractive reserve model emerged from decades of conflict at the frontier of the Brazilian Amazon (Schmink and Wood 1992). Activist Chico Mendes and fellow rubber tappers, a group of forest dwellers traditionally dedicated to natural latex collection for rubber production, organized a movement based in Acre to protect their forest livelihoods against encroaching land grabbers, cattle ranchers, and loggers. As a result, the relatively large (970,550 ha) and symbolic CMER was among the first extractive reserves created in 1990. Today, CMER represents a collection of landholdings managed by approximately 2000 individual households (WWF 2015). Landholdings are organized around traditional latex collection; each landholding consists of at least two rubber trails (approximately 100 ha each) tracing routes of naturally distributed rubber trees (Hevea brasiliensis). Landholdings vary greatly in size; as of 2015, the average landholding was 698 ha (WWF 2015). The reserve is jointly governed by ICMBio (Chico Mendes Institute of Biodiversity Conservation), an institutionally diverse Deliberative Council, and five local geopolitical resident associations. Decision-making power over most land-use activities is at the household level, and reserve residents are legally permitted to deforest up to $10 \%$ of the landholding for livelihood activities, including agriculture and animal husbandry.

Despite the minimal investment required of residents and relatively high returns on that investment, many households rejected participation in the examined logging project. Among other factors, logging in extractive reserves presumably remains controversial because of the history of social movement and struggle against loggers and ranchers in Acre. Additionally, gendered perspectives may also affect community support for logging projects, as well as participation in project-related activities; according to Montysuma and Cruz (2008), women interviewed in a nearby sustainable-use reserve were more critical of logging projects than were men.

\section{METHODS}

\section{Sample design}

At the time of study in 2014, two related logging projects were at different stages of development in two distinct areas of CMER. The first was in conjunction with the Association of Residents and Producers of CMER - Xapuri (i.e., AMOPREX), and had just initiated the first harvest. The second was with the Association of Residents and Producers of CMER - Brasiléia and Epitaciolândia (i.e., AMOPREBE), which had completed preharvest activities but had not yet initiated harvests. We focused on the latter, examining household participation and individual perceptions of the project in the eligible communities on and around a road network in seringais (former rubber estate areas) Filipinas, Porvir, and Porongaba. We used a nonprobability random sampling scheme to make three comparisons: (1) households participating in the logging project vs. nonparticipant households; and from within households, (2) individuals that support the project vs. nonsupporters, and (3) men vs. women.

A list and accompanying map of logging project participants created by Cooperfloresta served as a sampling frame from which we randomly selected participant households. Those households with completed timber inventories were categorized as first-cycle participants within each participant group. Participant landholdings without inventories (between zero and three per group) were categorized as future-cycle participants. Fifty percent of the total participating households were interviewed $(N=21)$. Of those, $88 \%$ of the total first-cycle participant households with mapped inventories are represented in our study, as well as $26 \%$ of the total future-cycle participant households. In total, 31 individuals $($ male $=18$, female $=13$ ) from 21 participant households were interviewed.

To select nonparticipant households, we developed a matched sample to mirror the random sample of participant households in terms of spatial distribution (including consideration of proximity to other participating and nonparticipating landholdings) and accessibility, i.e., time to walk to nearest point of river or road access. Screening criteria confirmed that families were both aware of the logging project and had declined the opportunity to participate in it. In total, 33 individuals (male = 19 , female $=14$ ) from 20 nonparticipant households were interviewed.

\section{Field data collection}

We conducted 64 semistructured interviews (Bernard 2011) in 41 households from June to August 2014. From each household, the decision-making male and female were each interviewed in isolation from the other. Interviews consisted of two components: (1) a questionnaire and (2) cultural domain analysis. The flexibility of semistructured interviews allows for unanticipated findings to emerge, and the application of varied methods supports the multidimensionality of the well-being concept, including its subjective components (Woodhouse et al. 2015). A CMER native accompanied and assisted the primary researcher during all interviews.

The following year, research results were presented, discussed, and validated among interview participants and community members at three different community group meetings. Results were similarly shared and deliberated with representatives from key organizations that work directly with CMER residents on resource management and development issues.

\section{Questionnaire}

The questionnaire served as a tool to gather baseline demographic and socioeconomic data. It also guided conversations relating to natural resource use, material and relational well-being, and the following open-response question about the logging project: Why are you participating or not participating in the logging project?

\section{Cultural domain analysis}

The cultural domain analysis focused on perceived positive and negative aspects of the logging project and their relative importance; it involved free listing and rank ordering (Bernard 2011) activities. Interview participants were first asked to list positive aspects about the logging project, then negative aspects. This exercise occurred early in the interview process to capture candid lists, avoiding the influence of cultural or logging-related interview questions on participant responses. At the close of the interview, a rank order exercise was administered using fixed lists of perceived positive and negative aspects of logging within CMER. These lists consisted of single statement ideas accompanied by illustrated representations that were color-coded positive (yellow) and negative (green; see Appendix 1 for 
Table 1. Summary of household-level variables used in a logistic model describing residents of Chico Mendes Extractive Reserve, 2014. $N=37$.

\begin{tabular}{|c|c|c|c|}
\hline Variable & Description & Mean & $\begin{array}{l}\text { Standard } \\
\text { deviation }\end{array}$ \\
\hline Direct road access & Resident home is within $0-5$ min walking distance from road $(0=$ no, $1=$ yes $)$ & 0.459 & 0.505 \\
\hline Landholding size & Area of landholding (ha) & 518.432 & 270.259 \\
\hline Forest cover & Self-reported percentage of forest cover on landholding & 0.965 & 0.033 \\
\hline Cattle & Number of heads of cattle per household & 13.811 & 14.830 \\
\hline Income from exractivism & $\begin{array}{l}\text { Income generated from extractive activities during the } 12 \text { mo prior to interview } \\
\text { (Brazil nut, latex, honey, acai), in R\$ }\end{array}$ & 8158.64 & 4209.576 \\
\hline Income from agriculture & $\begin{array}{l}\text { Income generated from agricultural products, including rice, beans, corn, } \\
\text { plantains, cassava, and farinha, during the } 12 \text { mo prior to interview, in } \mathrm{R} \$\end{array}$ & 572.338 & 909.97 \\
\hline Economic well-being & Wealth index based on the sum of estimated values of household items, in R\$ & 7530.595 & 3256.873 \\
\hline Education & $\begin{array}{l}\text { Number of years completed in school by the household head with the higher } \\
\text { number }\end{array}$ & 3.946 & 3.082 \\
\hline Empates & $\begin{array}{l}\text { One or more household members participated in empates during the rubber } \\
\text { tapper social movement }\end{array}$ & 0.459 & 0.505 \\
\hline Social capital & $\begin{array}{l}\text { Composite variable representing perceptions of community trust and support; } \\
\text { response values summed to create scores ranging from } 0.5 \text { (low) to } 4 \text { (high) }\end{array}$ & 2.905 & 0.857 \\
\hline Perception of well-being & $\begin{array}{l}\text { Composite variable representing various aspects of well-being related to } \\
\text { livelihood outcomes; response values summed to create scores ranging from } 5 \\
\text { (low) to } 11.5 \text { (high) }\end{array}$ & 9.351 & 1.572 \\
\hline Participation $^{\dagger}$ & Household-level participation in logging project $(0=$ no, $1=$ yes $)$ & 0.514 & 0.507 \\
\hline
\end{tabular}

examples). Participants organized positive list items $(N=7)$ in order of importance and negative list items $(N=11)$ in order of concern $(1=$ most important/concerning $)$. For all participants, each statement was read aloud and the drawing explained at least once, and thereafter as needed.

The master lists of positive and negative ranking items used in the research site were compiled beforehand in a conceptually similar sustainable-use reserve where a comparable logging project had occurred since 2002. The reserve residents share similar land-use and social histories and cultural rubber tapper identity as those in CMER and live in similar proximity to a regional town (approximately $30 \mathrm{~km}$ ). We also pretested the questionnaire with key informants.

\section{Data analysis}

Descriptive statistics were generated for 11 researcher-selected, household-level variables (Table 1). These included indicators to measure objective aspects of well-being pertaining to five categories of material and relational livelihood assets (natural, physical, financial, human, and social) as well as one measure of subjective well-being. Direct road access and landholding size were used as indicators for physical assets. Self-reported deforested area in hectares was calculated as a percentage of each landholding's total area, then inverted to represent percentage of forest cover. Thus, percentage of forest cover served as an indicator for natural assets. The number of heads of cattle, extractive income, agricultural income, and a wealth index based on material household items was created and associated with financial assets. The material nature of cattle and household assets was noted, but these items were categorized as financial assets; cattle can function like easily liquefied bank accounts in the context of CMER (Salisbury and Schmink 2007), and the wealth index served as a proxy for economic well-being. Years of education and historic participation in empates, i.e., pacifist standoffs against deforestation during the rubber tapper social movement, reflected human assets. Social capital, a social asset, was a composite variable assessing individual-level perceptions of trust and community support. The perception of well-being variable was a multi-item indicator of subjective well-being. For both social capital and perception of well-being variables, ordinal responses to individual items were converted to values and summed to create a composite score. Households with two household heads required averaging of the two individual scores to reflect the household level.

Logistic regression was performed in $\mathrm{R}$ ( $\mathrm{R}$ Core Team 2016) to test if household-level variables associated with sustainable livelihoods and well-being could predict participation in the logging project. The logistic model compared participating households $(N=19)$ and nonparticipating households $(N=18)$. Prior to running the regression, all variables were tested for collinearity. Paired plots generated also exposed households with outlier data points (Tukey 1977), resulting in the removal of four households (two participants and two nonparticipants) from the statistical analysis. Use of the Akaike Information Criterion (AIC) stepwise selection process produced a model of best fit, reducing the 11 researcher-selected variables to the following 4 variables: direct road access, annual income from agriculture, economic well-being, and education (Table 2).

We were also interested in comparing perceptions of logging by gender. Thus, we conducted a Wilcoxon rank sum test to compare men's $(N=37)$ and women's $(N=26)$ perception of their individual well-being.

Despite participation status, some individual opinions about logging diverged within a household. Therefore, to analyze individual perceptions in free lists, ranking, and open-ended responses, we compared individuals based on their position of support $(N=28)$ vs. nonsupport $(N=31)$ of the logging project. Neutral individuals $(N=5)$ were not included in this analysis. 
Table 2. Logistic model describing household participation in a logging project in Chico Mendes Extractive Reserve. Dependent variable is household participation in the logging project; $N=37$, AIC $=45.13$.

\begin{tabular}{lcccc}
\hline \hline Independent variable & Estimate & Standard error & $Z$ & $P>Z$ \\
\hline Direct road access & 1.4330982 & 0.9535198 & 1.503 & 0.1329 \\
Annual income from agriculture & -0.0008411 & 0.0004928 & -1.707 & 0.0878 \\
Economic well-being & -0.0004041 & 0.0001709 & -2.365 & 0.0180 \\
Education & 0.3913341 & 0.1650235 & 2.371 & 0.0177 \\
\hline
\end{tabular}

Positive and negative free lists from 64 individual interviews were analyzed separately. Once free list concepts were standardized, the frequency of list items was calculated in Visual Anthropac. Frequency was compared between groups of supporters and nonsupporters of the logging project. In total, respondents listed 27 positive items and 49 negative items. Items listed only once were eliminated from analysis because cultural domains, by definition, must be shared (Weller and Romney 1988). Lists were further truncated at natural breaks of diminishing frequency. In addition to comparison by logging support, lists were compared by gender.

Positive and negative lists from the ranking exercise were analyzed in Visual Anthropac (Borgatti 1988) to yield average rank order values. Average rank order was compared between individuals supportive and nonsupportive of the logging project and between men and women.

One open-response question "Why are you participating or not participating in the logging project?" was coded thematically in a four-step process to analyze reasons for logging project participation or rejection. First, responses were coded into basic idea units. These units were grouped into themes at two levels, and ultimately divided into four categories. Both themes and categories were analyzed by support for logging and gender.

\section{RESULTS}

\section{Logging project overview}

Political economic context and project development

In 1990, coincident with the welcomed backdrop of tenure stability imbued by the extractive reserve system, the Brazilian government rescinded a long-standing federal rubber subsidy that sent a shock through the rubber tapper livelihood system. With the value of rubber already in decline, tappers were obliged to diversify their land-use activities further, transitioning to heavier reliance on agriculture and cattle for income (Salisbury and Schmink 2007, Gomes et al. 2012). By 2009, the primary economic activities of CMER residents were livestock raising $(100 \%$ of residents interviewed), nontimber extractivism $(95 \%)$, and agriculture (33\%; SEMA 2010). During the 2000's, fueled by substantial financial support from the Inter-American Development Bank under an 8-yr umbrella Program for Sustainable Development for the State of Acre (PDSA; Portal do Governo do Acre, PDSA II: http://www.ac.gov.br/wps/portal/ acre/Acre/home/!ut/p/c5/vZHNcoJAEISfxQeIO8s R4VVF10EJaJctpBSBMXFSAB5-mDllEOSSyrTx6mpb7obRajXNa6zNK4ycY0vaIsijc8VzdvMpximvkyAWt5490o6GEBCIdqCwtf5o6TduVvl8MABUdrK9htGLq6bb9g6WMrMprA-KziwCWbQLlluSZiZeDPxyYiWS8HZoGftNA7fzAh--cRBUbYvhk1SDGGoy7o-
JmqwahmJgQ9VQ6CWite8sten2dFPtcczt5NwF0YzYr6TKaGiF5jFmbE 48YXLRaWY0aEhVp5PQu9dxNXIOVRJ6kiLctqQ09Qs7g6bn3ak9nT20Dtdr1f7yyrBBb8JoVpBu8wDw

Ttxb623axg2VJ4vjuTcvrSLbbnjToirLB0M-gSjL84Mhxm9sz4a16UOyNLn odcdijSueXr2H ew4SMgWomthhoIHkYBX Y0c8sf9YKvwpy52J4oDKo1609dor6qfSwQcLzmb2/d13/d3/

L2dBISEvZ0FBIS9nQSEh/), the government of Acre prioritized expanding forest-based economic development on both private and public lands. Designed, in part, to help sustain traditional extractivist activities, the state's strategy sought to grow the region's forest-based development infrastructure, technology, and product diversity (Kainer et al. 2003, Salisbury and Schmink 2007). The government expanded the concept of extractivism to include timber commercialization and initiated state-wide training programs and infrastructure for timber production (Schmink 2011), including furniture production poles and a certified flooring factory (Salisbury and Schmink 2007). Sustainable timber management projects were piloted in diverse forest-based communities (but not extractive reserves) as an approach to develop, improve, and encourage forest-based livelihoods compatible with traditional extractivist lifestyles (Duchelle et al. 2012).

By the time PDSA funding expired in 2010, formal logging had not yet occurred in extractive reserves, but preharvest activities were underway to open this category of protected forest to commercial logging in several CMER communities. In 2013, the Inter-American Development Bank extended funds to support a second phase of the PDSA (Portal do Governo do Acre, PDSA II), which is approximately when preharvest activities initiated in a second cluster of CMER communities. Thus, it is within this broader political economic context that the first two commercial logging initiatives in CMER emerged.

Throughout the aforementioned decade of forest economic development, most of the smallholder logging projects in Acre transitioned from ones initially intended to transfer timber management skills to local communities into a model whereby private logging firms were contracted for timber harvests and sales (Medina et al. 2009). A look at how CMER preharvest activities were approached suggests that this logging project did not neatly fit into either category, but more closely resembled the latter approach in which a third party is contracted to perform logging operations. In 2012, the state government's Standing Committee of Bids (Comissão Permanente de Licitação) announced a competition that would award a contract to the bidder proposing the lowest price for their technical assistance to develop forest inventories, a Sustainable Community Forest Management Plan (Plano de Manejo Florestal Sostentável Comunitário; PMFSC), and an Annual Operational Plan (Plano Operacional Anual; 
POA) in CMER - Brasiléia (Hechenberger 2013). The contract was awarded to Cooperfloresta (Cooperativa dos Produtores Florestais), a nonprofit cooperative that has managed community-based logging operations across the state since 2007. It emerged from a network of smallholders that participated in the community timber management pilot projects of the early 2000 s, and its objective is to assist communities to navigate the complexities of smallholder timber production. Since 2012, it has operated in all phases of production, including project planning, inventory, monitoring, transporting, sawing, and timber trading (Hechenberger 2013, Piketty et al. 2015). By 2013, Cooperfloresta had mapped forest inventories on individual landholdings and had produced the PMFSC and POA representing several communities in CMER - Brasiléia/Epitaciolândia.

\section{Logging project plans}

The general objective of the examined logging project was "to contribute to the development of the State of Acre, strengthening community forest management to make it ecologically, economically and socially sustainable," in addition to providing another source of income for CMER residents (stated in the PMFSC, page 10 [Cooperfloresta 2013]; translated by the authors). The project targeted an existing (rudimentary) road network that appears to act as the infrastructural backbone of the former rubber estate (seringal) of Filipinas. These roads are relatively highly trafficked and link the reserve to a nearby highway along its southern border. The regional urban center of Brasileía is situated approximately $15 \mathrm{~km}$ beyond the CMER perimeter. In addition to hopes of regulating informal timber extraction (ICMBio-MMA 2016) facilitated by these access ways, the focus on this area also allowed for a skinnier budget by eliminating the need to carve out new primary roads for timber transport. Therefore, households were only eligible to participate in the logging project if their landholdings and potential inventories were within $6 \mathrm{~km}$ of existing roads.

Cooperfloresta's management and operational plans outlined the use of reduced impact logging practices, including the use of skidders, or tractors used to transport roundwood from forest to roads. The guidelines suggested a maximum timber harvest of approximately $15 \mathrm{~m}^{3} / \mathrm{ha}$, from trees with a minimum diameter at breast height of $60 \mathrm{~cm}$. Each family could $\log$ an area up to 20 ha/yr. To minimize operational costs (i.e., construction of secondary roads), landholdings were grouped with up to three neighboring landholdings. Each year, the group's harvest quota would be logged on a single landholding, and profits would be distributed among all families in that group. The subsequent year, logging would occur on the second landholding of the group, and again, profits would be shared by all families, etc. These groups were decided by CMER residents during planning meetings. Depending on local geography, households could designate up to $80 \%$ of their landholding's total area to timber management, $20 \%$ of which would be classified as permanent preservation area. Timber management areas were off-limits for agriculture, pasture, and timber extraction for subsistence purposes, whereas traditional extractivist activities (e.g., Brazil nut and latex collection) were permitted. CMER residents had little to no formal engagement in the project development processes beyond attending a handful of project-related community meetings and consenting to the future sale of their standing timber based on the market rate, approximately USD \$17 (R \$60) per cubic meter for all 30 species identified by Cooperfloresta as commercially and legally viable for harvest.

Logging project participation, livelihood assets, and well-being Households that opted to participate in the logging project were more educated $(P<0.05)$ and had lower levels of economic wellbeing than those who did not $(P<0.05$; Table 2$)$. When wealth index values were divided into three levels (low, middle, and high), the proportion of participant and nonparticipant households represented in each level demonstrates an inverse relationship between project participation and economic well-being (Fig. 1). Also, as income from agriculture increased, participation in the logging project tended to decrease $(P<0.10)$.

Fig. 1. Levels of economic well-being and logging project participation in Chico Mendes Extractive Reserve. An inverse relationship between economic well-being and logging project participation status may be observed when economic well-being is divided into three ordinal levels: low, middle, and high.

Households with low economic well-being were predominantly logging project participants $(73 \%)$, whereas households with high economic well-being were predominantly nonparticipants $(71 \%)$.

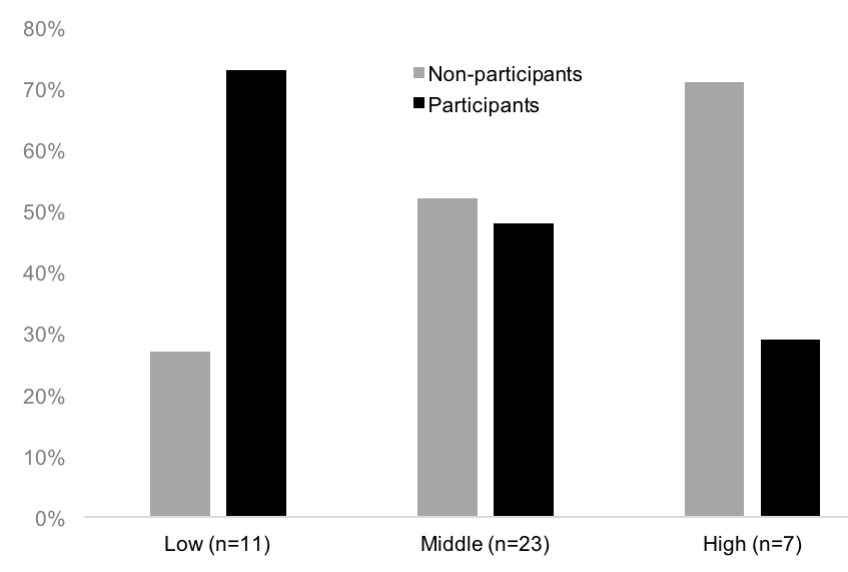

The Wilcoxon rank sum test indicated that women tended to have more positive perceptions of their well-being compared to men $(P=0.065)$. This difference suggests that men and women hold distinct perceptions of well-being despite living in the same household, so we ran a second Wilcoxon rank sum test to compare participant and nonparticipant household-level perceptions of well-being. However, there was no statistical difference in perception of well-being between these groups.

Supporters of the logging project most frequently listed income (79\% of supporters) among positive aspects of the project, whereas nonsupporters most frequently reported that nothing about the logging project was positive (42\%; Fig. 2). Compared by gender, positive lists yielded similar results. The most frequently listed items among men and women (both supporters and nonsupporters) were income and improved roads.

Supporters most frequently reported forest degradation and deforestation $(39 \%)$ as negative aspects of the project (Fig. 3). Nonsupporters most frequently listed the price of standing stems 
Fig. 2. Free list results comparing positive perceptions of the logging project between project supporters and nonsupporters and between men and women in Chico Mendes Extractive Reserve, Acre, Brazil.

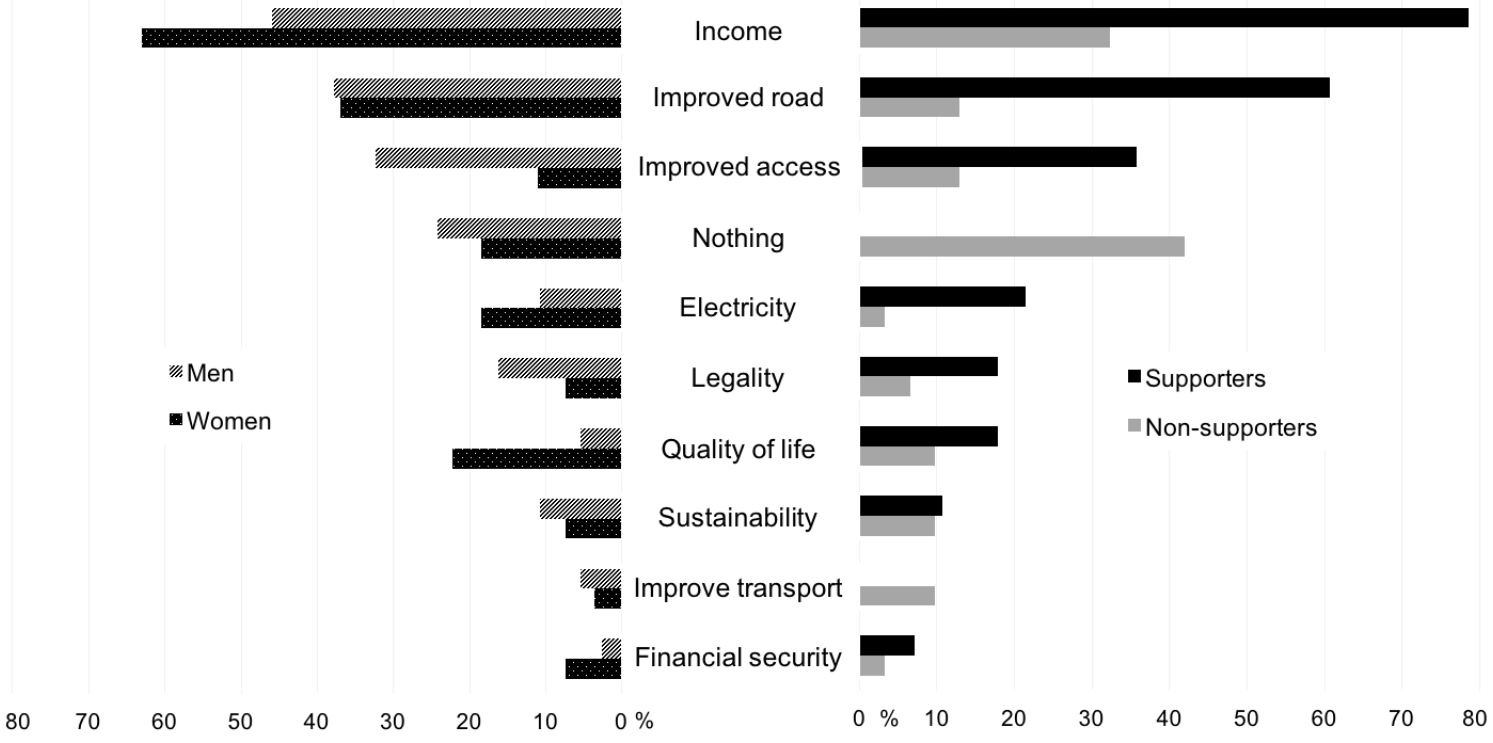

being unequal to their value $(52 \%)$. Unlike the positive free lists, gendered negative lists were more varied. Women free-listed deforestation $(52 \%)$, whereas the most common concern among men was the price of standing stems being unequal to their value $(46 \%)$.

Overall, results from the rank order activity showed little variation across comparison groups (see Appendix 3 for details). Improved road access emerged as an important benefit. Supporters were most concerned with the low price of timber, whereas nonsupporters were most concerned with animal habitat loss; however, logging supporters also shared this latter concern because they ranked this list item in second place. Notably, women ranked in last place the item that men found most concerning, "The government will make more money than reserve residents." All groups agreed that "The number of larger trees will decline," was of little concern.

Reasons to log or not were coded thematically into five categories (natural or environmental, financial, physical, social, and governance), the first four relating to livelihood assets, and analyzed by logging support and gender (Fig. 4; see Appendix 4 for details). Supporters of the logging project most frequently cited financial (37\% of responses) reasons for participation, whereas nonsupporters of logging responded with reasons related to natural assets $(35 \%)$. Project-supporting men most frequently cited financial reasons (income), whereas project-supporting women most frequently reported social reasons, for supporting logging (new or improved roads). Among nonsupporters, men most often qualified their participation status with reasons related to governance (project methods). Nonsupporting women, in contrast, most frequently cited environmental concerns (negative effects on the forest).

\section{DISCUSSION}

The objective of this study was to build understanding about the potential impact of a logging project on the well-being of local residents of a comanaged sustainable-use protected area. We focused on the resident perspective, aiming to bring light to resident perceptions about the project and the reasons why local people with a history of nontimber extraction decided to support or not to support logging. Many traditional communities in Amazonia, the Congo basin (i.e., de Blas et al. 2009), and in geographically smaller areas of old-growth tropical forest globally are confronted with weighty demands on increasingly scarce tropical timber resources (Laurance et al. 2014). While not generalizable, our results highlight both important differences and similarities in terms of tested variables reflecting material and relational livelihood assets contributing to well-being and personal convictions among respondent groups. Our findings can inform the design and implementation of nonindustrial logging projects carried out in tropical forests under comanagement schemes worldwide. Finally, our results contribute insights into the universal governance challenges surrounding comanagement of sustainable-use protected areas that seek both to support community well-being and to conserve nature.

\section{Material well-being: factors of participation and potential impacts of logging}

Financial

The logging project's financial component was an important factor in residents' decisions to participate. The prospect of additional household income appealed to members of all groups, but it seems that for many, the price of timber quoted in the project management plan was highly influential in their final decision. Our logistic model explaining household project participation revealed that households of higher economic well-being were less 
Fig. 3. Free list results comparing negative perceptions of the logging project between project supporters and nonsupporters and between men and women in Chico Mendes Extractive Reserve.

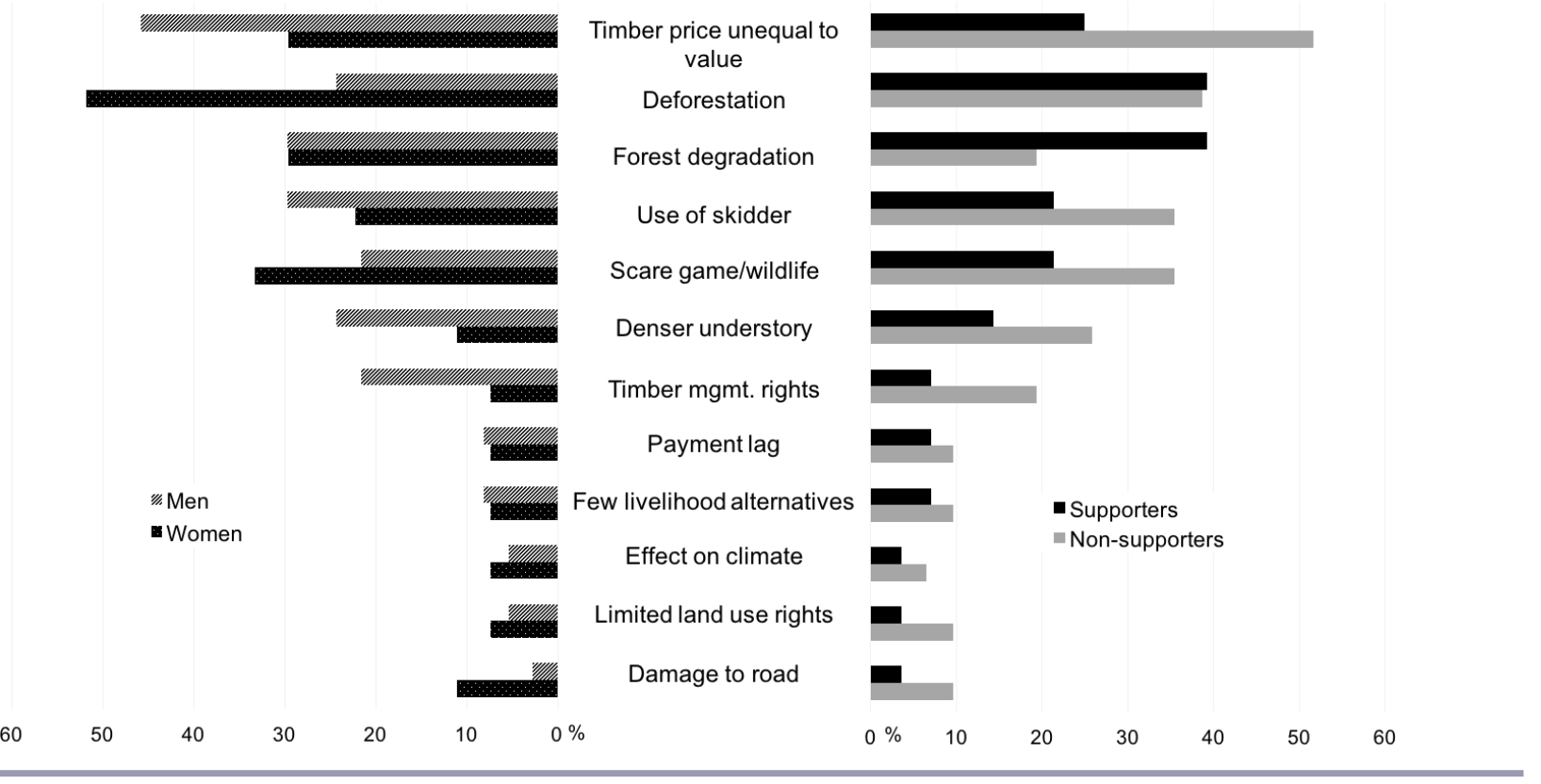

likely to participate than poorer ones (Table 2). Free lists (Figs. 2 and 3), ranked lists, and open-ended responses explaining household participation (Fig. 4) all supported this finding, suggesting that for households with greater financial need, the price of timber, while generally perceived as low, may have been enough to motivate participation. Households with a relatively stronger sense of financial security perhaps held off on logging because they could afford to do so. Numerous nonsupportive individuals expressed interest in participation but opted against it because they perceived the timber price as low.

Similarly, residents considered the opportunity costs and potential benefits of logging vs. alternative land uses (Pokorny and Pacheco 2014). Some land-use options permitted within the reserve were preceived as limited, and participation in the logging project presented an attractive opportunity to bolster household financial assets. In two similar CMER rubber estates (seringais), forest resource extraction remained the primary source of income for lower income households, whereas off-farm labor and cattle sales were primary sources for higher income households (Gomes 2009; R. H. Wallace, unpublished manuscript). Cattle are an easily liquefiable resource, one that reproduces relatively quickly (Salisbury and Schmink 2007), and represent a rapidly growing pop-cultural symbol across the region (Hoelle 2015). Augmenting cattle raising, however, risks pushing the deforestation limits on individual landholdings and requires capital. Multiple respondents predicted that project profits would be reinvested in animals such as cattle, which was confirmed by at least three participants who explicitly mentioned this intent.

We acknowledge the potential limitations of measuring economic well-being using a wealth index as a proxy. However, notably in our CMER context, where lack of infrastructure, remote access, and household isolation is common, ownership of material household items or lack thereof can significantly facilitate or challenge quality of life. For example, ownership of a motorcycle by especially remote households could critically aid in an emergency. Income plays a similarly critical role in accessing basic services, most of which are only available outside of the reserve. The need for cash and the costs accrued in travel are illustrated in the following example: $76 \%$ of households interviewed qualified for monthly cash transfers from federal programs (Bolsa Família and Bolsa Verde) that were created to assist families living below or under extreme poverty lines (Ministério do Meio Ambiente, Bolsa Verde program: http://www.mma.gov.br/ desenvolvimento-rural/bolsa-verde; Caixa, Bolsa Família program: http://www.caixa.gov.br/programas-sociais/bolsa-familia/ Paginas/default.aspx). To collect a Bolsa Família payment, residents must (pay for) travel to the nearest federal bank, which, for research participants, was the nearest city center, either Xapuri or Brasiléia. For the many of these residents relying on public road transportation, the travel costs alone can consume approximately $22-43 \%$ of that monthly payment (personal communication; calculations are based on a hypothetical family with one child [payment of R \$32] and one youth [payment of R $\$ 38$ ] and use of public road transport from CMER to the city [a flat price of $\mathrm{R} \$ 15$; $\mathrm{R} \$ 30$ roundtrip]; if the family lives in extreme poverty, it would collect an additional $\mathrm{R} \$ 70$, representing the lower percentage of income cost of $22 \%$ ).

Our logistic model (Table 2) suggests that households that earn more income from agricultural crops tend not to participate in the logging project. However, there was little correlation between agricultural income and economic well-being (1.1\%). Similarly, while accessibility logically facilitates agricultural sales, there was little correlation between agricultural income and access. In this logging project, inventoried areas are henceforth reserved for timber extraction and therefore exclude other potential uses of 
Fig. 4. Reasons for and against logging project participation among residents of Chico Mendes Extractive Reserve were divided into five categories and compared by resident support and gender.

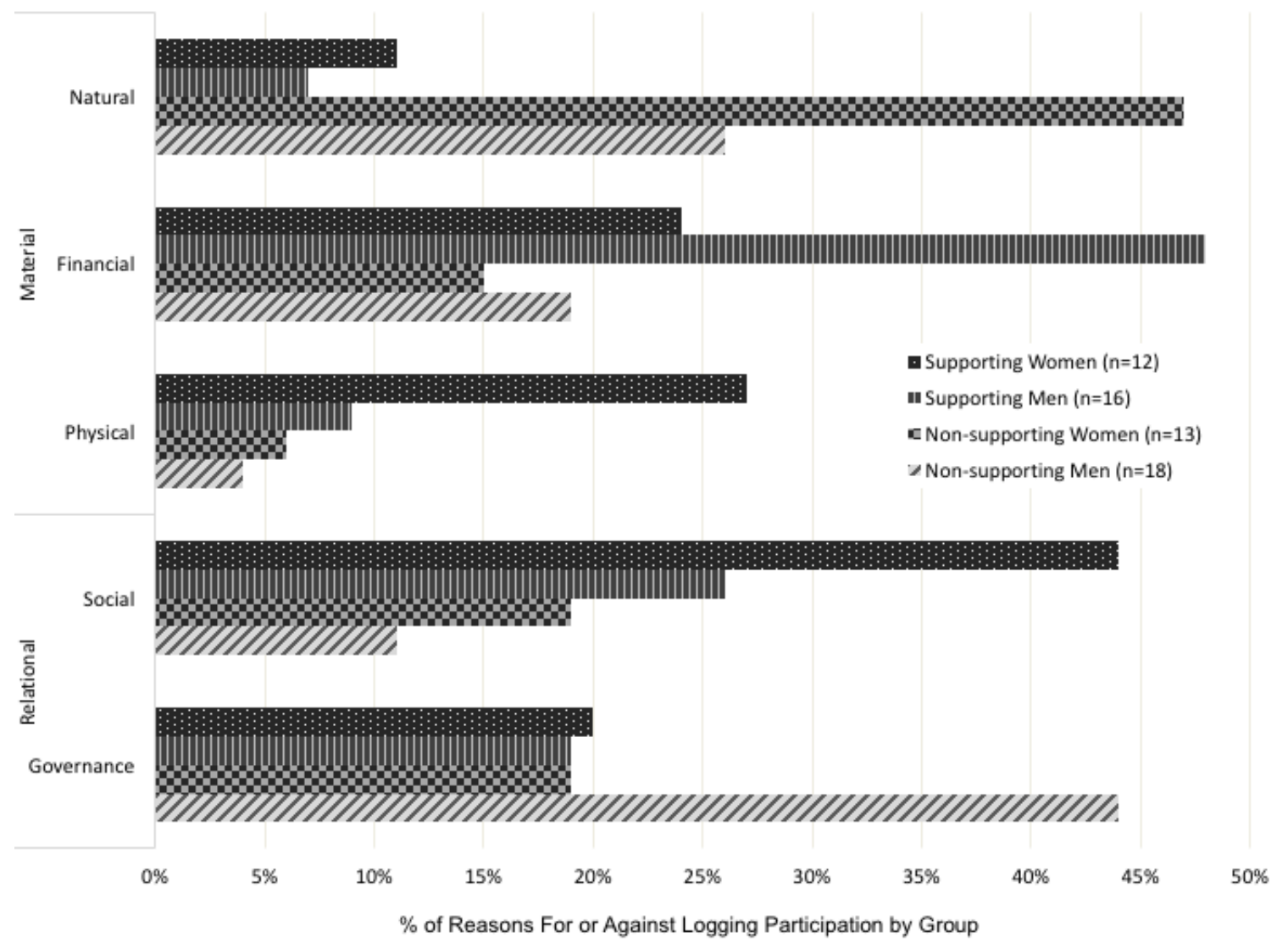

that land (i.e., agriculture) for the foreseeable future. However, the proportion of area on landholdings potentially zoned for timber management would not exceed $80 \%$, while the permissible area for complementary field- or pasture-based activities cannot exceed $10 \%$ of landholdings. Thus, perhaps families reliant on income from agriculture considered participation in the logging project a potential opportunity cost if inventories required accessible area that overlapped with current or potential agricultural lands near the household and road access.

\section{Physical}

The results clearly demonstrate the hope that residents felt that logging would improve collective physical assets in CMER, specifically, new roads and the prospect of electricity. Following income, these indirect benefits were the most widely listed positive aspects of the project, and in the ranking exercise, improved road access was considered the most important benefit of the project unanimously across support status and gender groups. Improved infrastructure would improve access to health and education services and could reduce the costs of travel in terms of time and money. Electricity could similarly save time and cut costs. For example, electricity would allow the possibility of basic electronic appliances such as washing machines, which could liberate some portion of the time women spend washing their family's laundry by hand, or freezers, which could conserve fresh food and thus time spent on food production or time lost by food spoilage.

Natural

Some residents, mostly nonsupporters, linked the project to exacerbation of environmental uncertainty: a threat to forest extraction activities and a potential contributor to increasingly erratic ecological conditions. The methods proposed in the logging project plan, specifically the use of skidders, had a strong and negative influence on some perceptions of the project because individuals linked skidders with forest degradation. Because livelihoods are so embedded in the ecological system, residents also feared that in addition to generic environmental harm, skidder use may specifically threaten forest-based activities such as hunting by scaring off wildlife and nontimber forest product extractivism by damaging forest trails. Finally, some residents expressed concern that the project would diminish timber resources preferred for local (subsistence) construction. There was also concern about the project's potential effect on climate and water resources. One nonparticipant expressed unease and suspicion with deforestation over time: "Twenty years ago there were more fish; I don't know if it is because of deforestation. The climate has changed a lot since I was a child, and I suspect that it is because of deforestation." Others felt uncertain about the 
project's long-term effects on the availability of natural resources for future generations.

In contrast, some supporters expected the project to yield more sustainable resource-use outcomes, and several others felt an increased sense of security with the legalization of logging for income. The legality of the project was the fifth most frequent positive list item $(18 \%)$ among supporters of the logging project (Fig. 2). Although no information on informal logging was gathered, we observed the well-known fact that timber traffic flows along the main roads of the reserve. Therefore, if households engaged in needs-based commercial logging but felt uncomfortable with the illegality of it, participation in the legal logging project offered a more secure alternative.

\section{Human}

The logistic model results indicated that logging project participants were more educated than nonparticipants. However, years of education correlated with age, and although not tested, access and opportunity have improved substantially over recent decades. The average age of individuals in participating households was $40 \mathrm{yr}$ compared to $49 \mathrm{yr}$ in nonparticipating households. Access to education increased as roads were constructed, social networks expanded into regional cities, and local transport permeated into accessible regions of CMER. There was also a correlation between age and religion, with older individuals tending to identify as Catholic, and younger ones as non-Catholic (i.e., one of various denominations of Protestant). Therefore, this result may reflect a broader story of a gradually changing demographic across generations.

It seems the proposal to fell trees in Acre continues to be a difficult sell after the rubber tapper social movement organized to prevent encroaching deforestation in the 1980s (Kainer et al. 2003, Rezende de Azevedo and Giacini de Freitas 2003). We therefore expected social memory, or the linking of past experiences (McIntosh et al. 2000, Folke et al. 2005) such as the pacifist empates, to influence resident decisions and perceptions. Because of the potentially visceral memories of an ideologically and even life-threatening experience, we expected nonparticipants to be more likely to report direct involvement in the movement. Numerous individuals interviewed recounted stories from the movement, and some even shared anecdotes of their friendship with activist Chico Mendes. Therefore, it was surprising that among participating households, $48 \%(N=10)$ had family members that had been involved in empates compared to $40 \%(N$ $=8$ ) among nonparticipating households. Together with changing conditions and opportunities delivered by access, this observation highlights the dynamic nature of attitudes and relationships with the past in CMER.

\section{Relational well-being: gender and comanagement}

Gender and well-being

Despite some overlap, gender roles in CMER tended to be well defined. Men expressed more concern with fulfilling the financial needs of the household than did women, and they more consistently listed, ranked, and cited financial issues either as highly important or concerning. In contrast, women frequently listed financial aspects during the positive free list (the first activity) only. The differences in these responses could similarly indicate differences in the control of financial resources. The tendency of male control of household money was observed in
CMER during data collection and has been documented elsewhere in rural Amazonia (e.g., Shanley et al. 2011, Schmink and Gómez-Garcia 2015). For example, in a study of timber management in Bolivia, men typically retained exclusive access to cash income, whereas women, in some cases, were unaware of the financial balance (Cronkleton and Bolanos 2005). Across rural Amazonia, men generally make household decisions, particularly regarding the forest domain, and are expected to be primary income earners (Shanley et al. 2011, Schmink and Gómez-Garcia 2015).

Our results suggest that women had less control in the decision to participate in the logging project. In seven cases, women interviewed said the reason they were participating or not participating was because of their husband's decision; some agreed with them while others did not (reflected in Fig. 4, "social"). Women reported less knowledge about the logging project details compared to men, which signals women's overall lower participation in logging project activities. This finding supports literature describing Amazonian women's minimal participation in timber management associations, management activities, and timber transactions, consequently leaving women with limited access to the knowledge and benefits of timber projects (Stone 2003, Vázquez García 2013, Schmink and GómezGarcia 2015).

An increase in women's involvement in the logging project could not only benefit gender equity, it could improve conservation outcomes. Open-ended responses to the question of why or why not participate in the logging project illuminated distinct sets of interests across the four comparison groups (Fig. 4): 48\% of supportive men's responses pertained to financial aspects; $44 \%$ and $27 \%$ of supportive women's responses pertained to social (again, reflecting their cooperation with their husbands' decision making) and physical assets, respectively; $44 \%$ of nonsupportive men's responses pertained to governance issues; and $47 \%$ of nonsupportive women's responses pertained to concerns about the security of natural assets. This diversity suggests that engaging a balance of men's and women's perspectives could produce a project design that more accurately represents reserve interests, and presumably the outcome would address a wider range of reserve needs. Studies from around the world indicate that an increase in women's participation may also contribute positively to group function in resource management. For example, Agarwal (2009) found that women's participation in decision making in community forest groups in India and Nepal improved forest governance, resource allocation, and the sustainability of forest resources. Similarly, Molinas (1998) found that women had a significantly positive effect on cooperation in forest management in Paraguay. Women also have demonstrated the ability to mitigate elite capture of benefits during the process of decentralization (de Vries and Sutarti 2006, Syamsuddin et al. 2007, Komarudin et al. 2008), which could be particularly relevant during initial stages of the logging project. Therefore, a deliberate attempt to integrate women into project planning (and beyond) would likely benefit both the process and longer term outcomes of extractive reserve logging.

Comanagement and well-being

Well-being depends on institutions that govern relationships between individuals and groups as well as between people and their environment. Conservation interventions have the potential 
to support relational aspects of well-being such as improving governance, alleviating poverty, and catalyzing social change and participation levels (Woodhouse et al. 2015). However, across project participant and nonparticipant households, many individuals articulated their general dissatisfaction with project governance. Logging by professionals in partnership with smallholders has been increasingly promoted as a suitable and relatively new model for timber management throughout the Amazon (Benneker et al. 2005, Lima et al. 2006, Pacheco 2006, Medina et al. 2009). Despite the potential for a mutually beneficial arrangement, CMER resident perceptions reflect a variety of concerns similar to those reported by other Amazonian communities that have engaged in comparable logging partnerships during the past decade (Nepstad et al. 2005, Medina et al. 2009). Our findings clearly indicate that reserve residents were minimally involved in the crafting of the project. This low level of inclusion in project rulemaking reflects local involvement in governance at the reserve level: Vadjunec (2011) reported that less than one-quarter of residents participated in reserve rulecreation processes. In terms of the logging project, the final package offered was more typical of industrial reduced-impact logging operations (Rockwell et al. 2007) and less consistent with resident visions of logging in the reserve. Residents were aware of, if not attracted to, the project's benefits, but conceivably, those benefits (i.e., income and roads) could be acquired independently of the timber management model proposed. For some residents, the benefits on the table were insufficient to compensate for the risk of degrading their forests and livelihoods.

Discussion about the externally directed proposal to legally log reserve timber raised issues (mostly among nonsupporters) about forest rights held by the reserve's comanaging parties, and specifically, about withdrawal and management rights (see Cronkleton et al. 2012, Rights and Resources Initiative 2012) of timber. Many residents expressed frustration that the government (vs. residents) would have the right to authorize management, harvest, and negotiation of reserve timber when little of its value would remain or be reinvested in the reserve. Further, reserve residents reported being almost entirely excluded from project development (or decision-making) processes. During one interview, a project participant stated, "The government is exploiting those who take care of the reserve. The resident has no rights [in the logging project]." This same sentiment is reflected in men's ranking the item "The government will make more money than the residents" as the most concerning aspect of the project and, notably, was ranked last (least concerning) among women. Thus, there is clearly a gendered tension in the relationship between residents and their comanaging counterparts related to the perceived constraints on rights and resource use and the way the government regulates them. Men's greater concern about logging project income (in keeping with their "provider" role) and greater distrust and frustration with the government may be reflected in the tendency of men to have a lower sense of wellbeing compared to women. In contrast, a study about the influence of community-based forest management (CBFM) on well-being in Tanzania demonstrated the potential positive power of decentralizing control over local resources. Despite no increase in household-level material well-being after $10 \mathrm{yr}$ of CBFM, the villages reported continuing CBFM activities because they perceived greater and more exclusive control over their forest resources and monitoring, and that this generated a strong sense of pride within their community (Gross-Camp 2017).

Negative perceptions of logging project governance we recorded suggest a possible link between the practical limitations that weaken equitable reserve comanagement and resident participation in project development in which rights and resources are at stake. The comanagement governance model adopted by extractive reserves supports the idea that community participation will improve resource management and conservation. In practice, however, extractive reserves are commonly administered in a top-down fashion with insufficient monitoring and the presence of knowledge gaps between comanaging counterparts (Berkes and Seixas 2004, Boyd 2008). In this case, top-down governance, or external regulation in the context of resource use in the extractive reserve, seems to have decreased resource users' perception of their own autonomy, which can diminish intrinsic motivation to manage resources responsibly (DeCaro and Stokes 2008). Further, effective monitoring may become more vulnerable to dynamic external forces such as provision of sufficient management tools. At the time of our study, ICMBio representatives and reserve residents alike reported the shared perception that the local ICMBio stations suffered from insufficient allocation of human resources to address the diversity and scope of the reserve management challenges.

The broader proposition of legal logging within CMER, however, ought not to hinge on a single project design or model. It is possible that a logging project rooted in local perceptions of wellbeing could facilitate livelihood development and foment empowerment rather than simply provide additional income. In fact, most nonparticipants interviewed stated that they would actually support a project based on rules and methods devised at least in part by the communities themselves. Residents suggested alternative logging methods during interviews, such as salvage logging of naturally felled timber and the use of oxen and wagons for transport. A logging project design accommodating local technology and methods may not maximize efficiency or timber yields from a market perspective (Pokorny and Pacheco 2014), but, based on the perceptions and reasoning reported here, adjustments to logging methods and equipment in the management plan could make legal timber extraction more accessible and attractive to reserve residents. Several middle-aged rubber tappers lamented that their bodies simply no longer supported the 12-h days of traversing rubber trails. One such individual described how, despite having retired from tapping rubber, he still loves being in the forest and that he feels more at home in the forest than in his own house. A logging project in which reserve residents engaged directly with their timber resources could potentially supplement not only household income but household livelihoods and well-being, as well as maintain or even strengthen linkages to the forest. Cases exist of successful community-based logging operations inside sustainableuse protected areas that could guide future logging project development (e.g., Espada and Sobrinho 2015, Humphries et al. 2015).

Mediating external forces and local realities in comanagement Global timber markets impose many challenges to the viability of small-scale timber production in remote Amazonian forests 
(Pokorny and Pacheco 2014), and resident perceptions may reflect some degree of information gap about such macro-level forces that shaped various components of the timber management plan. For example, the estimated timber price and extraction methods that prioritize logging efficiency for greater economic returns (Rockwell et al. 2007) were perceived by residents as unfair (i.e., timber price) or inconsiderate of local conditions (i.e., skidder technology). These perceptions may stem from limited or specific timber management experience. Anyone aware of informal timber sales would be accustomed to inflated prices that bypass certain costs altogether (i.e., administrative). One resident expressed skepticism of payment per cubic meter of extracted roundwood because the local familiar metric was by sawn planks; such a system could take advantage of the extractivist. Although local ecological knowledge is extensive (Wallace 2004), the relative impact of skidders on forest health and wildlife could have been overestimated by residents.

The logging project represents a state-level effort to fulfill multiple conservation and development objectives at multiple levels (PMFSC objectives). Presumably, it is also acting in the interests of its financial supporters. An analysis of macro-level forces was beyond the scope of our study, but their contribution to the complexity of balancing conservation and development goals in a complex social-ecological system such as CMER is acknowledged. Thus, if any combination of external forces (i.e., those generated by donors, markets, political agendas, or stability) or internal forces (i.e., community struggles to organize effectively) constrained opportunities for interested but untrained local residents to participate in logging operations, then perhaps the government and other relevant stakeholders could focus more attention on improving social-governance relations in comanagement. Effective community-based conservation development projects depend on strong institutional linkages, capacity building, trust building, and mutual learning (Berkes 2007). In this case, those factors could manifest in strategies to improve communication and transparency about the project, coordinating at multiple levels of reserve leadership. Information from the management plan is technically available to residents, but to many, it is not readily accessible. In fact, when asked, most residents were unable to name which organization(s) had visited their community to discuss the logging project. Devolving the responsibility of seeking and understanding project details to local residents, some of whom are illiterate or minimally educated and living in remote areas, is impractical and perhaps even negligent of the realities of CMER conditions. Communicating better information about pricing, the rationale behind the methods and technology selected, and a basic understanding of commodity chains could relieve some of the tension in the comanagement relationship, especially among resident men. Deliberation, i.e., communication processes in which interested parties engage in discussions, share multiple perspectives and opinions, reflect on information, and assess outcomes, is critical to sorting out competing understandings of human-ecosystem interactions (Stern 2005, Reid et al. 2006). More dialogue could create opportunities for residents to gain more power and control at minimal expense to the project, for example, in negotiating inventory maps more sensitive to Brazil nut or rubber trails. A case in Guyana identified several factors for local support in resource management, including capacity building, more local control over resources, and increased dialogue between local users and the government facilitated by a locally trusted nongovernmental organization (Berkes and Seixas 2004). An effort to foster trust and mutual understanding, including acknowledgement of local perceptions and concerns reported here, could be one relatively affordable and potentially effective action to help clarify perceptions, increase mutual understanding, and gradually improve social relations, and thus well-being, between resident communities and representatives of external organizations.

\section{Scope and limitations}

Although our study can inform similar cases worldwide, it is a unique case. Our sample is small, despite representing a substantial percentage of the research population, and reflects interest in a specific logging project. Also, we refrained from raising the topic of illegal logging with research participants, despite its central role in the existence of the logging project and potential impact on CMER households. Informal logging is a contentious topic among reserve residents and between residents and external regulators, and we feared that researcher-participant trust would be lost by asking questions on that topic. However, some residents brought the topic up independently, often speaking in general terms rather than about specific individuals. Similarly, some logging project details remain incomplete. At the time of our study, no actual logging had yet occurred, so these perceptions are limited to the preharvest phase and do not reflect any subsequent outcomes or perceptions of outcomes. Finally, well-being indicators are most accurate when defined in conjunction with the research population (Woodhouse et al. 2015). Although our results suggest links between CMER perceptions and commonly applied indicators of material and relational well-being, they do not necessarily reflect CMER resident conceptions of well-being.

\section{CONCLUSION}

Across the globe, logging in areas targeted for conservation has the potential to offer a balanced approach to attaining both biodiversity conservation and human well-being goals. Our findings, however, demonstrate that the decision to log or not to log presented most residents with what seemed more like a choice between trade-offs: conservation or material well-being. Participating in logging could bring desired benefits of additional income, roads, and perhaps even electricity; however, logging may seemingly contradict longstanding forest values. There appeared to be an underlying tension between respect for the reserve's ideological conservation foundation for strictly nontimber forest product harvest (or in other words, traditional extractivist activities) and the government's more pragmatic promotion of timber extraction. Some individuals decided to support or reject the logging project based on allegiance to either of these approaches. For most residents, who shared mixed feelings, however, decisions to participate in or reject the logging project were complex, generally less reflective of positions about logging, and often boiled down to economic need, a very basic indicator of material well-being. The income to be earned through this logging project would subsidize many families working to make ends meet. In this sense, the top-down project design correctly identified income as an important logging outcome, but it was clearly not the only one. For households that were better off, the 
price offered for their standing timber was insufficient to tip their decision across the threshold between perceived costs (not limited to the financial sense) and benefits of the project.

Finally, local resident perceptions of the logging project revealed issues with the governance approach and forest resource management practices currently promoted (or experimented with) by the government. Perceptions about the logging project further signaled weaknesses in the underlying comanagement relationship between reserve residents and the government, which, based on perceptions reported, had roots in mutual information gaps and distrust. Regardless of the particular constraints around this project, creating opportunities for information exchange, to incorporate local and gendered perspectives in project processes and design, and to build trust among stakeholder groups could be a feasible strategy toward strengthening comanagement institutions that mediate conservation interventions and govern certain aspects of resident well-being. This quality of the relationship is especially important given the increasingly complex challenges of reconciling market demand with tropical timber supply, human well-being with local ecosystems, and unrelenting development pressure with conservation throughout the global tropics.

Responses to this article can be read online at: http://www.ecologyandsociety.org/issues/responses. $\mathrm{php} / 9995$

\begin{abstract}
Acknowledgments:
The authors are tremendously grateful to the survey participants and their households. We extend particular thanks to the following colleagues for making this research possible: Lúcia Wadt, Joziane Silva Evangelista, Marianne Schmink, Denis Valle, Richard Wallace, Ricardo Mello, and Rohit Patra. This work was supported by the Tinker Foundation, the Brazilian Agricultural Research Corporation (Embrapa)-Acre, and World Wildlife Fund-Acre.
\end{abstract}

\section{LITERATURE CITED}

Agarwal, B. 2009. Gender and forest conservation: the impact of women's participation in community forest governance. Ecological Economics 68(11):2785-2799. https://doi.org/10.1016/ j.ecolecon.2009.04.025

Agrawal, A., A. Chhatre, and R. Hardin. 2008. Changing governance of the world's forests. Science 320(5882):1460-1462. http://dx.doi.org/10.1126/science.1155369

Allegretti, M. H. 1989. Reservas extrativistas: uma proposta de desenvolvimento da floresta amazônica. Pará Desenvolvimento 25:2-29.

Ascher, W. 1995. Communities and sustainable forestry in developing countries. ICS Press, San Francisco, California, USA.

Barber, C. P., M. A. Cochrane, C. M. Souza Jr., and W. F. Laurance. 2014. Roads, deforestation, and the mitigating effect of protected areas in the Amazon. Biological Conservation 177:203-209. http://dx.doi.org/10.1016/j.biocon.2014.07.004
Benneker, C., J. Bejarano and M. A. Coca Villarroel. 2005. Experiencias de manejo forestal comunitario en Bolivia. CEADES, SNV, and Wageningen University, Santa Cruz de la Sierra, Bolivia.

Berkes, F. 2007. Community-based conservation in a globalized world. Proceedings of the National Academy of Sciences 104 (39):15188-15193. https://doi.org/10.1073/pnas.0702098104

Berkes, F., and C. S. Seixas. 2004. Lessons from community selforganization and cross-scale linkages in four Equator Initiative Projects. Centre for Community-based Resource Management, Natural Resources Institute, University of Manitoba, Winnipeg, Canada. [online] URL: http://hdl.handle.net/10625/34594

Bernard, H. R. 2011. Research methods in anthropology: qualitative and quantitative approaches. Fifth edition. AltaMira, Lanham, Maryland, USA.

Borgatti, S. 1988. ANTHROPAC: an MS/DOS program with documentation. University of California, Irvine, California, USA.

Borrini-Feyerabend, G., M. T. Farvar, J. C. Nguinguiri, and V. Ndangang. 2000. comanagement of natural resources: organising, negotiating and learning-by-doing. Kasparek, Heidelberg, Germany.

Boyd, E. 2008. Navigating Amazonia under uncertainty: past, present and future environmental governance. Philosophical Transactions of the Royal Society B: Biological Sciences 363 (1498):1911-1916. http://dx.doi.org/10.1098/rstb.2007.0023

Chambers, R., and G. R. Conway. 1991. Sustainable rural livelihoods: practical concepts for the 21 st century. IDS Discussion Paper 296. IDS, Brighton, UK. [online] URL: https://www.ids.ac. uk/publication/sustainable-rural-livelihoods-practical-concepts-forthe-21st-century

Cooperativa dos Produtores Florestais Comunitários (Cooperfloresta). 2013. Plano de manejo florestal sustentável comunitário: Associação dos Moradores e Produtores da Resex Chico Mendes de Brasiléia e Epitacionlândia. Cooperfloresta, Brasiléia, Brazil.

Coulthard, S., D. Johnson, and J. A. McGregor. 2011. Poverty, sustainability and human wellbeing: a social wellbeing approach to the global fisheries crisis. Global Environmental Change 21 (2):453-463. http://dx.doi.org/10.1016/j.gloenvcha.2011.01.003

Cronkleton, P., and O. Bolanos. 2005. Case 1: Bolivia. Pages 202-211 in C. J. Pierce Colfer. The complex forest: communities, uncertainty, and adaptive collaborative management. Resources for the Future, Washington, D.C., USA.

Cronkleton, P., J. M. Puhlin, and S. Saigal. 2012. Co-management in community forestry: how the partial devolution of management rights creates challenges for forest communities. Conservation and Society 10(2):91-102. http://dx.doi. org/10.4103/0972-4923.97481

de Blas, D. E., M. Ruiz Pérez, J. A. Sayer, G. Lescuyer, R. Nasi, and A. Karsenty. 2009. External influences on and conditions for community logging management in Cameroon. World Development 37(2):445-456. https://doi.org/10.1016/j. worlddev.2008.03.011 
de Vries, W., and N. Sutarti. 2006. Gender equity: revealing the reality for the women of Jambi. CIFOR Governance Brief 29. Center for International Forestry Research, Bogor, Indonesia. http://dx.doi.org/10.17528/cifor/002159

DeCaro, D., and M. Stokes. 2008. Social-psychological principles of community-based conservation and conservancy motivation: attaining goals within an autonomy-supportive environment. Conservation Biology 22(6):1443-1451. http://dx.doi.org/10.1111/ j.1523-1739.2008.00996.x

Duchelle, A. E., M. R. Guariguata, G. Less, M. A. Albornoz, A. Chavez, and T. Melo. 2012. Evaluating the opportunities and limitations to multiple use of Brazil nuts and timber in Western Amazonia. Forest Ecology and Management 268:39-48. http://dx. doi.org/10.1016/j.foreco.2011.05.023

Ehringhaus, C. 2005. Post-victory dilemmas: land use, development, and social movement in Amazonian extractive reserves (Brazil). Dissertation. Yale University, New Haven, Connecticut, USA.

Espada, A. L. V., and M. V. Sobrinho. 2015. Manejo comunitário e governança ambiental para o desenvolvimento local: análise de uma experiência de uso sustentável de floresta na Amazônia. Administração Pública e Gestão Social 7(4):169-177. https://doi. org/10.21118/apgs.v7i4.669

Folke, C., T. Hahn, P. Olsson, and J. Norberg. 2005. Adaptive governance of social-ecological systems. Annual Review of Environment and Resources 30:441-473. https://doi.org/10.1146/ annurev.energy.30.050504.144511

Gibson, C. C., M. A. McKean, and E. Ostrom, editors. 2000. People and forests: communities, institutions, and governance. MIT Press, Cambridge, Massachusetts, USA.

Gomes, C. V. A. 2009. Twenty years after Chico Mendes: extractive reserves' expansion, cattle adoption and the evolving self-definition among rubber tappers in the Brazilian Amazon. Dissertation. University of Florida, Gainesville, Florida, USA.

Gomes, C. V. A., J. M. Vadjunec, and S. G. Perz. 2012. Rubber tapper identities: political-economic dynamics, livelihood shifts, and environmental implications in a changing Amazon. Geoforum 43(2):260-271. https://doi.org/10.1016/j.geoforum.2011.09.005

Gross-Camp, N. 2017. Tanzania's community forests: their impact on human well-being and persistence in spite of the lack of benefit. Ecology and Society 22(1):37. https://doi.org/10.5751/ ES-09124-220137

Hajjar, R., R. A. Kozak, J. El-Lakany, and J. L. Innes. 2013. Community forests for forest communities: integrating community-defined goals and practices in the design of forestry initiatives. Land Use Policy 34:158-167. https://doi.org/10.1016/j. landusepol.2013.03.002

Hayes, T. M. 2006. Parks, people, and forest protection: an institutional assessment of the effectiveness of protected areas. World Development 34(12):2064-2075. https://doi.org/10.1016/j. worlddev.2006.03.002

Hechenberger, S. 2013. Licitação em prestação de serviços em manejo florestal para o Estado: o caso COOPERFLORESTA. Universidade Federal do Paraná, Rio Branco, Brazil.
Hoelle, J. 2015. Rainforest cowboys: the rise of ranching and cattle culture in western Amazonia. University of Texas Press, Austin, Texas, USA.

Humphries, S., D. Andrade, and D. McGrath. 2015. Brazil: Cooperativa Mista da Flona do Tapajós (COOMFLONA): a successful community-based forest enterprise in Brazil. Pages 61-84 in D. Macqueen, A. Bolin, and M. Greijmans, editors. Democratising forest business: a compendium of successful locally controlled forest business organisations. International Institute for Environment and Development, London, UK. [online] URL: http://pubs.iied.org/13581IIED/

Instituto Chico Mendes de Conservação da Biodiversidade Ministério do Meio Ambiente (ICMBio-MMA). 2016. O que é o manejo madeireiro comunitário? Informativo Comunitário: Reserva Extrativista Chico Mendes 2015(4):1-2.

Jenkins, C. N. and L. Joppa. 2009. Expansion of the global terrestrial protected area system. Biological Conservation 142 (10):2166-2174. https://doi.org/10.1016/j.biocon.2009.04.016

Kainer, K. A., M. Schmink, A. C. Pinheiro Leite, and M. J. Da Silva Fadell. 2003. Experiments in forest-based development in western Amazonia. Society and Natural Resources 16 (10):869-886. https://doi.org/10.1080/716100619

Keller, M., G. P. Asner, G. Blate, J. McGlocklin, F. Merry, M. Peña-Claros, and J. Zweede. 2007. Timber production in selectively logged tropical forests in South America. Frontiers in Ecology and the Environment 5(4):213-216. http://dx.doi. org/10.1890/1540-9295(2007)5[213:TPISLT]2.0.CO;2

Komarudin, H., Y. Siagian, and C. Colfer. 2008. Collective action to secure property rights for the poor: a case study in Jambi province, Indonesia. CAPRi Working Paper 90. International Food Policy Research Institute, Washington, D.C., USA. [online] URL: http:// www.ifpri.org/publication/collective-action-secure-property-rightspoor

Laurance, W. F., J. Sayer, and K. G. Cassman. 2014. Agricultural expansion and its impacts on tropical nature. Trends in Ecology and Evolution 29(2):107-116. https://doi.org/10.1016/j.tree.2013.12.001

Lele, U., V. Viana, A. Verissimo, S. Vosti, K. Perkins, and S. A. Husain. 2000. Brazil: forests in the balance: challenges of conservation with development. World Bank, Washington, D.C., USA. http://dx.doi.org/10.1596/0-8213-4761-6

Lima, E., F. Merry, D. Nepstad, G. Amacher, C. Azevedo-Ramos, P. Lefebvre, and F. Resque. 2006. Searching for sustainability: forest policies, smallholders, and the trans-Amazon highway. Environment 48(1):26-38. https://doi.org/10.3200/ENVT.48.1.26-38

McIntosh R. J., J. A. Tainter, and S. K. McIntosh, editors. 2000. The way the wind blows: climate, history, and human action. Columbia University Press, New York, New York, USA.

McKean, M. A. 2000. Common property: what is it, what is it good for, and what makes it work. Pages 27-55 in C. C. Gibson, M. A. McKean, and E. Ostrom, editors. People and forests: communities, institutions, and governance. MIT Press, Cambridge, Massachusetts, USA.

Medina, G., B. Pokorny, and B. M. Campbell. 2009. Community forest management for timber extraction in the Amazon frontier. 
International Forestry Review 11(3):408-420. https://doi. org/10.1505/ifor.11.3.408

Menton, M. C. S., F. D. Merry, A. Lawrence, and N. Brown. 2009. Company-community logging contracts in Amazonian settlements: impacts on livelihoods and NTFP harvests. Ecology and Society 14(1):39. https://doi.org/10.5751/ES-02831-140139

Ministério do Meio Ambiente (MMA). 2006. Plano de Manejo: Reserva Extrativista Chico Mendes. Ministério do Meio Ambiente, Xapuri, Brazil. [online] URL: http://www.icmbio.gov. br/portal/images/stories/imgs-unidades-coservacao/resex_chico_mendes. pdf

Molinas, J. R. 1998. The impact of inequality, gender, external assistance and social capital on local-level cooperation. World Development 26(3):413-431. http://dx.doi.org/10.1016/S0305-750X (97)10066-3

Montysuma, M., and T. A. Cruz. 2008. Perspectivas de gênero acerca de experiências cotidianas no seringal cachoeira - Acre (1964-2006). Historia Unisinos 12(3):219-236. [online] URL: http://revistas.unisinos.br/index.php/historia/article/view/5432

Nepstad, D., C. Azevedo-Ramos, and E. Lima. 2005. Governing the Amazon timber industry for maximum social and environmental benefits. Forests, Trees and Livelihoods 15 (2):183-192. http://dx.doi.org/10.1080/14728028.2005.9752519

Organisation for Economic Cooperation and Development (OECD). 2011. How's life? Measuring wellbeing. OECD, Paris, France. $\mathrm{http}$ ://dx.doi.org/10.1787/9789264121164-en

Ostrom, E. 1990. Governing the commons: the evolution of institutions for collective action. Cambridge University Press, Cambridge, UK.

Ostrom, E. 2009. A general framework for analyzing sustainability of social-ecological systems. Science 325 (5939):419-422. http://dx.doi.org/10.1126/science.1172133

Pacheco, D. 2006. Manejo forestal comercial comunitario en propiedades colectivas indígenas de las tierras tropicales de Bolivia. Centro de Estudios para la Realidad Económica y Social (CERES), Cochabamba, Bolivia.

Persha, L., A. Agrawal and A. Chhatre. 2011. Social and ecological synergy: local rulemaking, forest livelihoods, and biodiversity conservation. Science 331(6024):1606-1608. http:// dx.doi.org/10.1126/science.1199343

Piketty, M.-G., I. Drigo, P. Sablayrolles, E. Araujo, J. W. P. Pena, and P. Sist. 2015. Current barriers threatening income generation from community-based forest management in the Brazilian Amazon. Pages 71-82 in P. Katila, G. Galloway, W. de Jong, P. Pacheco, and G. Mery, editors. Forests under pressure - local responses to global issues. International Union of Forest Research Organizations, Vienna, Austria. [online] URL: https://www.iufro. org/download/file/27941/6596/ws32-PII_ch03_Brazilian_Amazon_pdf/

Pokorny, B., and P. Pacheco. 2014. Money from and for forests: a critical reflection on the feasibility of market approaches for the conservation of Amazonian forests. Journal of Rural Studies 36:441-452. http://dx.doi.org/10.1016/j.jrurstud.2014.09.004
Porter-Bolland, L., E. A. Ellis, M. R. Guariguata, I. Ruiz-Mallén, S. Negrete-Yankelevich, and V. Reyes-García. 2012. Community managed forests and forest protected areas: an assessment of their conservation effectiveness across the tropics. Forest Ecology and Management 268:6-17. http://dx.doi.org/10.1016/j.foreco.2011.05.034

Putz, F. E., P. A. Zuidema, T. Synnott, M. Peña-Claros, M. A. Pinard, D. Sheil, J. K. Vanclay, P. Sist, S. Gourlet-Fleury, B. Griscom, J. Palmer, and R. Zagt. 2012. Sustaining conservation values in selectively logged tropical forests: the attained and the attainable. Conservation Letters 5(4):296-303. http://dx.doi. org/10.1111/j.1755-263X.2012.00242.X

R Core Team. 2016. R: a language and environment for statistical computing. R Foundation for Statistical Computing, Vienna, Austria.

Reid, W. V., F. Berkes, T. Wilbanks, D. Capistrano, editors. 2006. Bridging scales and knowledge systems: concepts and applications in ecosystem assessment. Island Press, Washington, D.C., USA.

Rezende de Azevedo, T., and A. Giacini de Freitas. 2003. Annex 1: forest certification in Brazil: the parallel evolution of community forest management in the Brazilian Amazon and FSC certification. Forest Trends, Washington, D.C., USA. [online] URL: http:// www.forest-trends.org/publication_details.php?publicationID=321

Ribot, J. C. 2002. Democratic decentralization of natural resources: institutionalizing popular participation. World Resources Institute, Washington, D.C., USA. [online] URL: http://pdf.wri.org/ ddnr full revised.pdf

Rights and Resources Initiative. 2012. What rights? A comparative analysis of developing countries' national legislation on community and indigenous peoples' forest tenure rights. Rights and Resources Initiative, Washington, D.C., USA. [online] URL: https:// rightsandresources.org/wp-content/exported-pdf/ whatrightsnovember13final.pdf

Rockwell, C., K. A. Kainer, N. Marcondes, and C. Baraloto. 2007. Ecological limitations of reduced-impact logging at the smallholder scale. Forest Ecology and Management 238 (1-3):365-374. http://dx.doi.org/10.1016/j.foreco.2006.11.002

Salisbury, D. S., and M. Schmink. 2007. Cows versus rubber: changing livelihoods among Amazonian extractivists. Geoforum 38(6):1233-1249. http://dx.doi.org/10.1016/j.geoforum.2007.03.005

Schmink, M. 2011. Forest citizens: changing life conditions and social identities in the land of the rubber tappers. Latin American Research Review 46(Special Issue):141-158. http://dx.doi. org/10.1353/lar.2011.0035

Schmink, M., and M. A. Gómez-Garcia. 2015. Under the canopy: gender and forests in Amazonia. CIFOR Occasional Paper 121. Center for International Forestry Research, Bogor, Indonesia. http://dx.doi.org/10.17528/cifor/005505

Schmink, M., and C. H. Wood. 1992. Contested frontiers in Amazonia. Columbia University Press, New York, New York, USA.

Scoones, I. 1998. Sustainable rural livelihoods: a framework for analysis. IDS Working Paper 72. Institute of Development Studies, Brighton, UK. [online] URL: https://www.ids.ac.uk/ publication/sustainable-rural-livelihoods-a-framework-for-analysis 
Secretaria de Estado de Meio Ambiente do Governo do Estado do Acre (SEMA). 2010. Diagnóstico socioeconômico e cadastro da Reserva Extrativista Chico Mendes - Plano Resex Sustentável. Instituto Chico Mendes de Conservação da Biodiversidade (ICMBio), Rio Branco, Brazil.

Serviço Florestal Brasileiro (SFB). 2016. Plano anual de outorga florestal 2017. SFB, Brasília, Brazil. [online] URL: http://www. florestal.gov.br/publicacoes/512-plano-anual-de-outorga-florestalpaof-2017

Shanley, P., F. C. Da Silva, and T. Macdonald. 2011. Brazil's social movement, women and forests: a case study from the National Council of Rubber Tappers. International Forestry Review 13 (2):233-244. http://dx.doi.org/10.1505/146554811797406570

Stern, P. C. 2005. Deliberative methods for understanding environmental systems. BioScience 55(11):976-982. https://doi. org/10.1641/0006-3568(2005)055[0976:DMFUES]2.0.CO;2

Stiglitz, J. E., A. Sen, and J.-P. Fitoussi. 2009. Report by the Commission on the Measurement of Economic Performance and Social Progress. Commission on the Measurement of Economic Performance and Social Progress, Paris, France. [online] URL: http://ec.europa.eu/eurostat/documents/118025/118123/Fitoussi+ Commission+report

Stone, S. S. 2003. From tapping to cutting trees: participation and agency in two community-based timber management projects in Acre, Brazil. Dissertation. University of Florida, Gainesville, Florida, USA. [online] URL: http://ufdc.ufl.edu/UFE0002421/00001

Summers, J. K., L. M. Smith, J. L. Case, and R. A. Linthurst. 2012. A review of the elements of human well-being with an emphasis on the contribution of ecosystem services. Ambio 41 (4):327-340. http://dx.doi.org/10.1007/s13280-012-0256-7

Syamsuddin, Neldysavrino, H. Komarudin, and Y. Siagian. 2007. Are community aspirations being accommodated in development plans?: a lesson from collective action in Jambi. CIFOR Governance Brief 34. Center for International Forestry Research, Bogor, Indonesia. http://dx.doi.org/10.17528/cifor/002240

Tukey, J. W. 1977. Exploratory data analysis. Addison-Wesley, Boston, Massachusetts, USA.

Vadjunec, J. M. 2011. Extracting a livelihood: institutional and social dimensions of deforestation in the Chico Mendes Extractive Reserve, Acre, Brazil. Journal of Latin American Geography 10(1):151-174. http://dx.doi.org/10.1353/lag.2011.0007

Vázquez García, V. 2013. Género y bosques: temas y enfoques en la literatura internacional. Revista Mexicana de Ciencias Forestales 4(16):10-21. [online] URL: http://www.scielo.org.mx/ scielo.php?script $=$ sci_arttext\&pid $=$ S2007-11322013000200002

Wallace, R. H. 2004. The effects of wealth and markets on rubber tapper use and knowledge of forest resources in Acre, Brazil. Dissertation. University of Florida, Gainesville, Florida, USA. [online] URL: http://etd.fcla.edu/UF/UFE0007082/wallace r. pdf

Weller, S. C., and A. K. Romney. 1988. Systematic data collection. Sage, Newbury Park, California, USA.
Westermann, O., J. Ashby, and J. Pretty. 2005. Gender and social capital: the importance of gender differences for the maturity and effectiveness of natural resource management groups. World Development 33(11):1783-1799. https://doi.org/10.1016/j. worlddev.2005.04.018

Woodhouse, E., K. M. Homewood, E. Beauchamp, T. Clements, J. T. McCabe, D. Wilkie, and E. J. Milner-Gulland. 2015. Guiding principles for evaluating the impacts of conservation interventions on human well-being. Philosophical Transactions of the Royal Society B 370:20150103. http://dx.doi.org/10.1098/ rstb.2015.0103

World Wildlife Fund (WWF). 2015. Guia informativo da gestão participativa na Reserva Extrativista Chico Mendes - Acre. WWF, Brasília, Brazil. [online] URL: https://www.wwf.org.br/ informacoes/?45544/guia-informativo-da-gestao-participativa-nareserva-extrativista-chico-mendes 
Appendix 1. Examples of illustrated list items used in the rank order activity about perceptions of logging in extractive reserves.

Fig. A1.1. One of seven illustrations representing positive list items used in the rank order activity. This item depicts greater access. Interview participants ranked drawings like this one in order of importance $(1=$ most important).

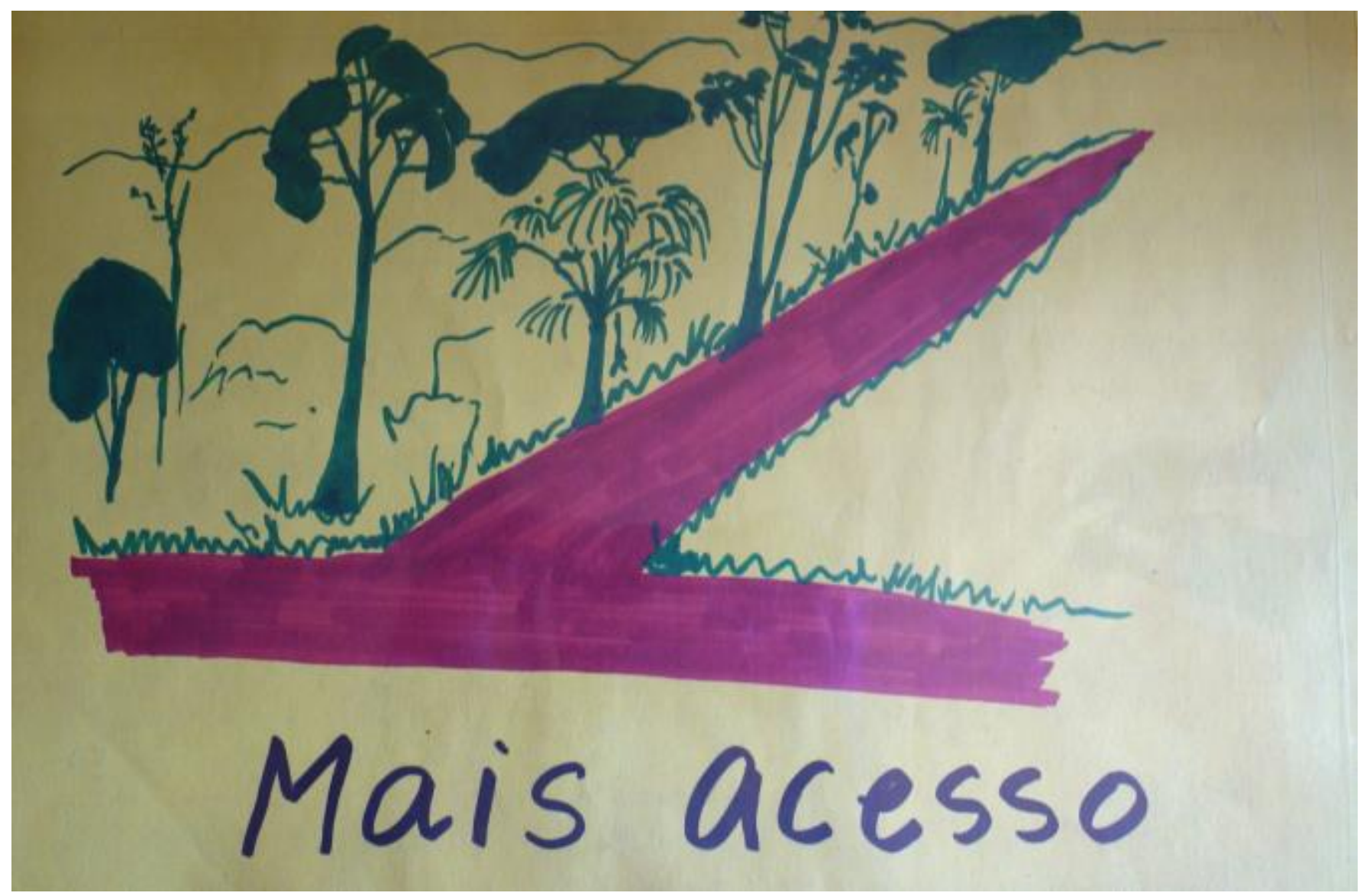


Fig. A1.2. One of eleven illustrations representing negative list items used in the rank order activity. This item depicts animal habitat loss. Interview participants ranked drawings like this one in order of concern $(1=$ most concerning).

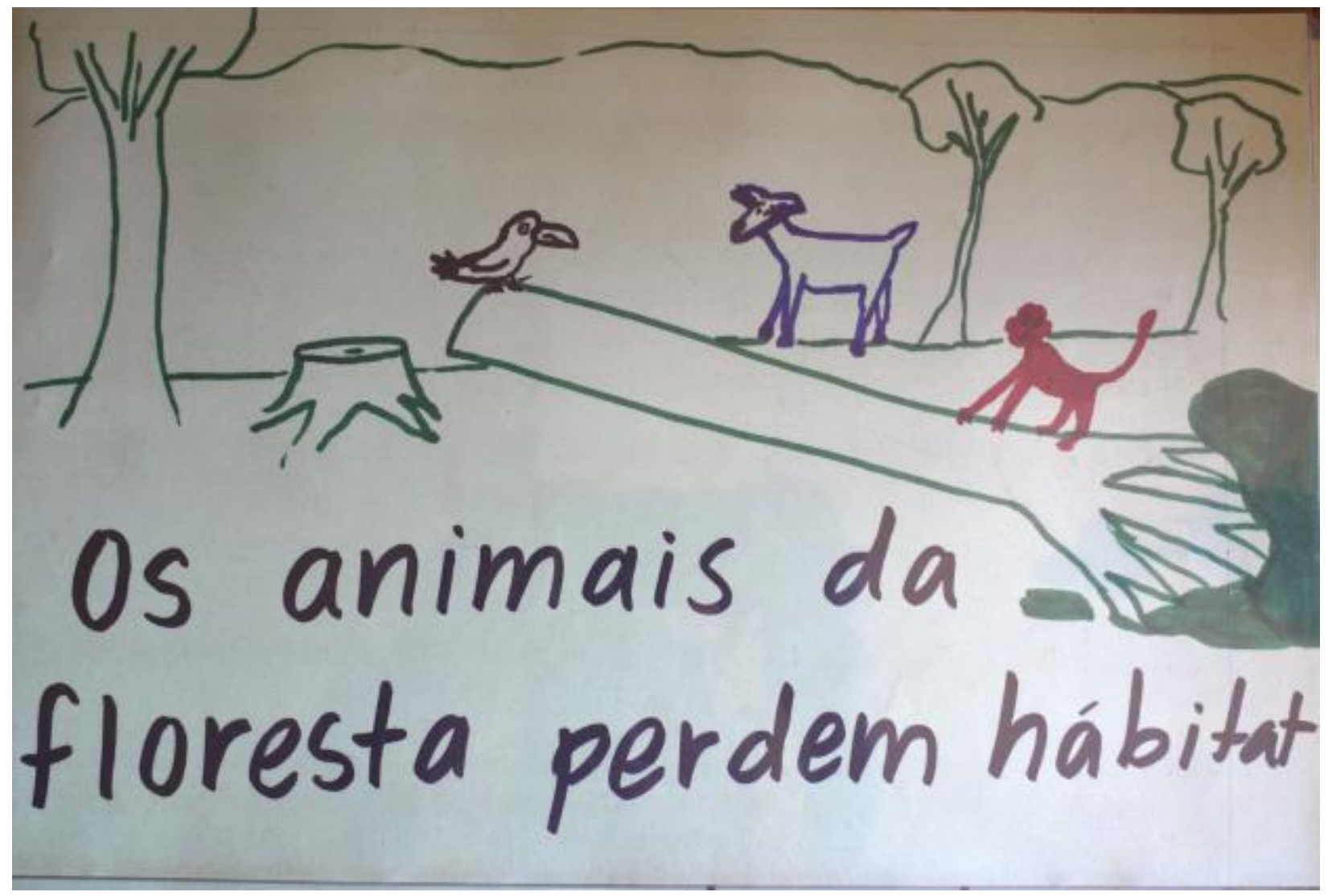




\section{Appendix 2. Variable Descriptions.}

Table A2.1. Questionnaire items used to create composite independent variables used in the household-level logistic regression model development regarding participation in a logging project in the Chico Mendes Extractive Reserve, Brazil, 2014.

\begin{tabular}{|c|c|c|}
\hline \multicolumn{3}{|c|}{ Composite independent variables } \\
\hline Social Capital & $\begin{array}{l}\text { 1) In general, do y } \\
\text { 2) Are you able to } \\
\text { example, if you ne } \\
\text { 1=sometimes; } 2=y\end{array}$ & $\begin{array}{l}\text { people in your community? }(0=\text { no; } 1=\text { partially; } 2=y e s) \\
\text { rom people in your community when you are in need, for } \\
\text { oney because someone in your family is sick? }(0=\text { no; }\end{array}$ \\
\hline Well-being & $\begin{array}{l}\text { 1) All things consi } \\
(0=\text { very unsatisfie } \\
\text { satisfied) } \\
\text { 2) Was your incon } \\
\text { 3) In comparison v } \\
\text { family is doing? ( } \\
\text { 4) How is your far } \\
\text { same; } 2=\text { better) } \\
\text { 5) Do you conside }\end{array}$ & $\begin{array}{l}\text { satisfied are you with your life during the last year? } \\
\text { sfied, } 2=\text { neither satisfied/unsatisfied, } 3=\text { satisfied, } 4=\text { very } \\
\text { th during the last year? }(0=\text { no; } 1=\text { sufficient; } 2=\text { yes }) \\
\text { amilies in the community, how do you consider your } \\
\text { =average, } 2=\text { better off }) \\
\text { compared to your situation } 5 \text { years ago? ( } 0=\text { worse; } 1=\text { the } \\
\text { munity a good place to live? }(0=\text { no; } 1=\text { partially; } 2=\text { yes) }\end{array}$ \\
\hline Economic well-being & $\begin{array}{l}\text { Household Item } \\
\text { Radio } \\
\text { Cellular phone } \\
\text { Wooden stove } \\
\text { Gas stove } \\
\text { Fire arm } \\
\text { Freezer } \\
\text { Television } \\
\text { Landline phone } \\
\text { Sofa } \\
\text { Refrigerator } \\
\text { Wardrobe closet } \\
\text { Solar panel } \\
\text { Generator } \\
\text { Wagon } \\
\text { Chainsaw }\end{array}$ & $\begin{array}{l}\text { Value }(R \$) \\
50 \\
110 \\
175 \\
575 \\
650 \\
750 \\
750 \\
800 \\
800 \\
900 \\
2,000 \\
2,100 \\
2,223 \\
2,250 \\
2,500 \\
\end{array}$ \\
\hline
\end{tabular}

Table A2.2. 'Social Capital' measures perceptions of trust and support in the respondent's relationship with their community. 'Well-being' measures satisfaction with life, relationships and progress within the community. For both 'social capital' and 'perception of well-being' variables, ordinal responses to individual items were converted to values and summed to create a composite score. Households with two household heads required averaging of the two individual scores to reflect the household level. 'Economic well-being' was based on a wealth index of household items and an average of their approximated new and used values. For each household, items owned were reported and the values of those items summed. Questionnaire items were adapted from Center for International Forestry Research (CIFOR)'s Poverty and Environment (PEN) prototype questionnaire, Annual Household Survey 2 (A2), version 4.4, September 2008. 


\section{Appendix 3 .}

Table A3.1. Results from rank order activity using fixed lists of positive aspects of logging in sustainable use protected areas (1=most important).

\begin{tabular}{|c|c|c|c|c|c|c|c|c|}
\hline Positive List Item & & upporters & & $\begin{array}{l}\text { Non- } \\
\text { ipporters }\end{array}$ & & Men & & omen \\
\hline Access to electricity & 3 & $(3.74)$ & 2 & $(3.24)$ & 2 & $(3.59)$ & 2 & (3.33) \\
\hline Improved road access & 1 & $(2.65)$ & 1 & $(2.06)$ & 1 & $(2.47)$ & 1 & $(2.19)$ \\
\hline $\begin{array}{l}\text { Increased forest monitoring than where there } \\
\text { is no logging }\end{array}$ & 7 & $(4.9)$ & 7 & $(4.61)$ & 7 & $(4.8)$ & 7 & $(4.7)$ \\
\hline Easy money requiring little work & 6 & $(4.55)$ & 6 & $(4.52)$ & 6 & $(4.42)$ & 6 & $(4.69)$ \\
\hline $\begin{array}{l}\text { A new livelihood for extractivists with few } \\
\text { Brazil nut and rubber trees on their } \\
\text { landholdings }\end{array}$ & 5 & $(4.2)$ & 5 & $(4.32)$ & 5 & $(4.17)$ & $4-5$ & $(4.4)$ \\
\hline Improved financial situation & 2 & $(3.67)$ & 3 & $(4.23)$ & 4 & $(4.06)$ & 3 & $(3.81)$ \\
\hline $\begin{array}{l}\text { Reduced deforestation compared to areas } \\
\text { without logging (i.e. areas dependent on } \\
\text { extractivism, agriculture and animal } \\
\text { husbandry only) }\end{array}$ & 4 & $(4.1)$ & 4 & $(4.3)$ & 3 & $(4.03)$ & $4-5$ & $(4.4)$ \\
\hline
\end{tabular}

Table A3.2. Results from rank order activity using fixed lists of negative aspects of logging in sustainable use protected areas $(1=$ most concerning).

\begin{tabular}{|c|c|c|c|c|c|c|c|c|}
\hline \multirow{2}{*}{$\begin{array}{l}\text { Negative List Item } \\
\text { The number of highly valued tree species will } \\
\text { diminish }\end{array}$} & \multicolumn{2}{|c|}{ Supporters } & \multicolumn{2}{|c|}{$\begin{array}{c}\text { Non- } \\
\text { supporters }\end{array}$} & \multicolumn{2}{|r|}{ Men } & \multicolumn{2}{|c|}{ Women } \\
\hline & 10 & $(6.32)$ & 10 & $(7.21)$ & 10 & $(7.22)$ & 6 & (6.19) \\
\hline Animals of the forest will lose habitat & 2 & $(4.81)$ & 1 & $(4.27)$ & 2 & $(4.7)$ & 1 & (4.3) \\
\hline $\begin{array}{l}\text { The understory will thicken where temporary } \\
\text { roads were created for timber transport by } \\
\text { skidder }\end{array}$ & 9 & $(6.23)$ & $3-4$ & $(5.18)$ & 5 & $(5.72)$ & 4 & $(5.63)$ \\
\hline It will be more difficult to hunt & 4 & $(5.7)$ & 2 & $(5.06)$ & 6 & $(5.81)$ & 2 & $(4.78)$ \\
\hline $\begin{array}{l}\text { People who do not know how to manage money } \\
\text { will end up without money and without trees }\end{array}$ & 11 & $(6.77)$ & 7 & $(6.52)$ & 9 & $(6.76)$ & 8 & $(6.46)$ \\
\hline $\begin{array}{l}\text { The government will make more money than } \\
\text { reserve residents }\end{array}$ & $7-8$ & $(6.07)$ & $3-4$ & $(5.18)$ & 1 & $(4.38)$ & 11 & (7.35) \\
\hline The price of timber is low & 1 & $(4.23)$ & 6 & $(5.73)$ & 3 & $(4.97)$ & 3 & $(5.07)$ \\
\hline Deforestation of neighboring trees & $7-8$ & $(6.07)$ & 9 & $(6.79)$ & 8 & $(6.51)$ & 7 & $(6.35)$ \\
\hline $\begin{array}{l}\text { The main roads will have many potholes caused } \\
\text { by the transport of timber }\end{array}$ & 3 & $(5.45)$ & 5 & $(5.58)$ & 4 & $(5.47)$ & 5 & $(5.58)$ \\
\hline $\begin{array}{l}\text { Logging technicians will make more money than } \\
\text { reserve residents }\end{array}$ & 6 & $(5.97)$ & 8 & $(6.7)$ & 7 & $(6.06)$ & 9 & (6.77) \\
\hline The number of large trees will diminish & 5 & $(6.96)$ & 11 & (7.79) & 11 & (7.63) & 10 & (7.12) \\
\hline
\end{tabular}


Appendix 4. Categories with sub-categories of reasons for (non-) participation in the logging project.

Fig. A4.1. Graph of five categories (Natural, Financial, Physical, Social, and Governance) with subcategories of reasons for participation or non-participation in the logging project, Chico Mendes Extractive Reserve, Brazil, 2014.

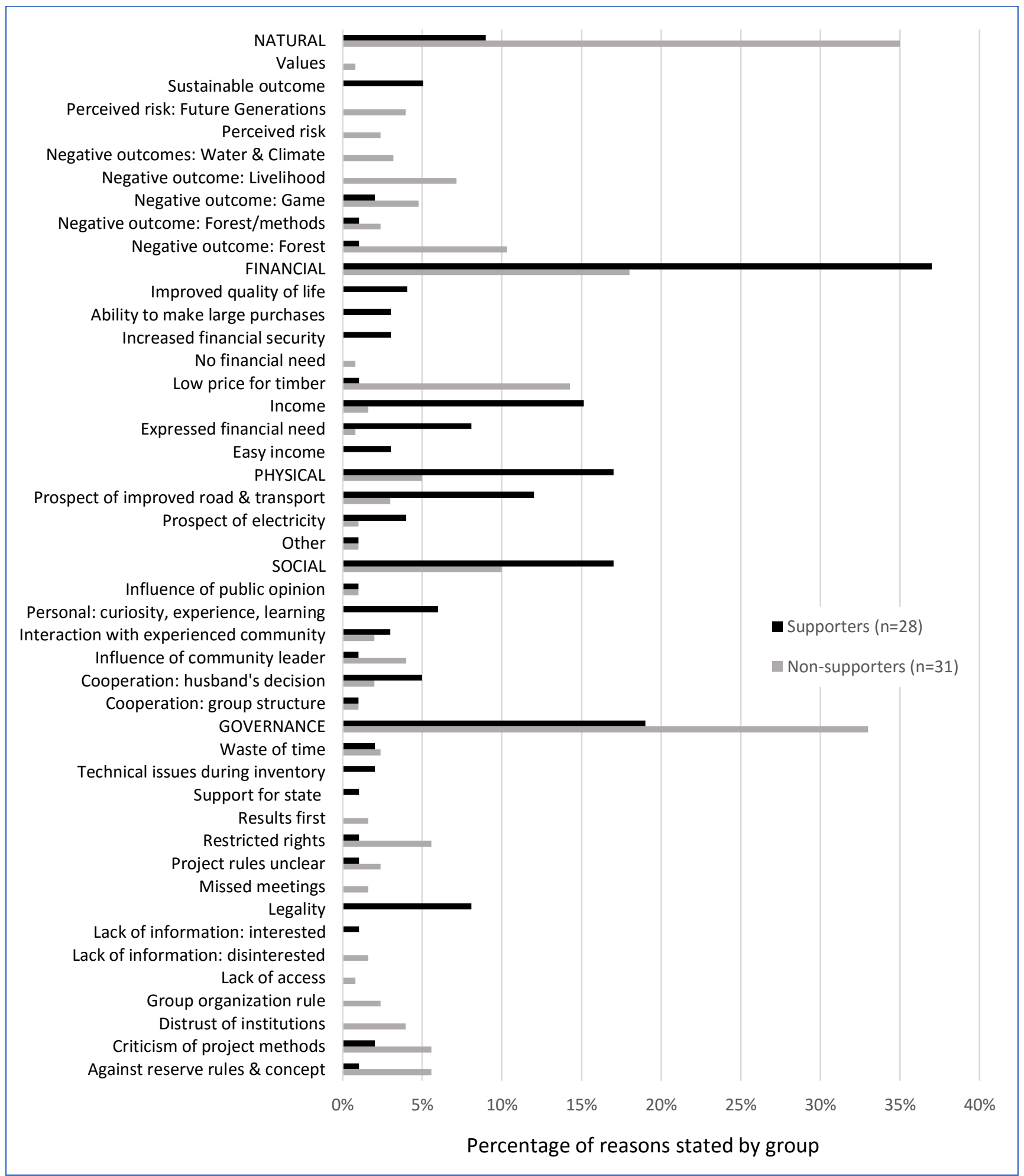

